\title{
TISSUE DISTRIBUTION OF A PEPTIDE TRANSPORTER mRNA IN SHEEP, DAIRY COWS, PIGS, AND CHICKENS
}

\author{
by \\ Hong Chen
}

Thesis submitted to the Graduate Faculty of the Virginia Polytechnic Institute and State University in partial fulfillment of the requirements for the degree of

\section{MASTER OF SCIENCE}

in

Animal Science

E. A. Wong, Co-Chairman

K. E. Webb, Jr., Co-Chairman

D. M. Denbow

July, 1998

Blacksburg, VA

Key Words: Peptide transporter, PepT1, Tissue, Messenger RNA, Intestine

Copyright 1998, Hong Chen 


\title{
TISSUE DISTRIBUTION OF A PEPTIDE TRANSPORTER mRNA IN SHEEP, DAIRY COWS, PIGS, AND CHICKENS
}

\author{
Hong Chen
}

\section{(ABSTRACT)}

To study the mRNA found in sheep omasal epithelium encoding for a peptide transport protein(s), a 446-bp cDNA fragment was cloned from sheep omasal epithelium RNA. The predicted amino acid sequence of this fragment was 85.8, 90.5, and 90.5 percent identical to rabbit, human, and rat PepT1, respectively. The fragment was radiolabeled for use as a probe to study the distribution of the mRNA in various tissues. Total RNA was extracted and mRNA was isolated from the epithelium of gastrointestinal segments and other tissues as indicated. Northern blot analysis was conducted using the radiolabeled probe. In sheep (5) and lactating Holstein cows (3), hybridization was observed with mRNA from the omasum, rumen, duodenum, jejunum, and ileum. The estimated size of mRNA was $2.8 \mathrm{~kb}$. No hybridization was observed with mRNA from the abomasum, cecum, colon, liver, kidney, and semitendinosus and longissimus muscles of either species or the mammary gland of the dairy cows. In pigs (6), the probe hybridized with mRNA from the duodenum, jejunum, and ileum. There was no hybridization with mRNA from the stomach, large intestine, liver, kidney, and semitendinosus and longissimus muscles. Two bands, 3.5 and $2.9 \mathrm{~kb}$ were observed with northern blot analysis, indicating two RNA transcripts that may result from alternative mRNA processing. In both Leghorns (15) and broilers (20), the strongest hybridization was found in the duodenum while the jejunum and ileum showed faint bands. The size of mRNA in chickens was $1.9 \mathrm{~kb}$. Other tissues, including the crop, proventriculus, gizzard, ceca, liver, kidney, and muscles showed no hybridization to the probe. In conclusion, mRNA for a peptide transport protein(s) is present in the small intestine of all animals examined and the omasal and ruminal epithelium of sheep and dairy cows. The size of the mRNA varied among species. 


\section{ACKNOWLEDGEMENTS}

I would like to thank Dr. K. E. Webb, Jr. for his encouragement, assistance, and patience throughout my graduate study and research and in the preparation of this manuscript. I thank him for the example of dedication to work he has provided to me. Without his efforts and support, I would never have begun, nor continued my academic development at Virginia Tech.

I am indebted to Dr. E. A. Wong for providing me with the opportunity to work in his laboratory. His technical support, guidance, comments, and discussions of my experiments helped me to continue and finish my research project.

I am grateful to Dr. D. M. Denbow for his assistance, helpful suggestions, and willingness to serve as my committee member.

I want to thank Don Shaw, Kris Lee, Kerry Waite, Martha McCollum, Kristy Weatherly, and Drs J. C. Matthews and K. Kurima for their friendship, discussions, and support during my study and research.

I want to express my deepest appreciation to my husband, friend, and colleague, YuanXiang Pan, for his support, criticism, discussion, and inspiration throughout my student life. 


\section{TABLE OF CONTENTS}

ABSTRACT

ACKNOWLEDGEMENTS

TABLE OF CONTENTS $\quad$ iv

LIST OF TABLES $\quad$ V

LIST OF FIGURES _ vi

CHAPTER I. INTRODUCTION 1

CHAPTER II. REVIEW OF LITERATURE 3

MOLECULAR CLONING AND STRUCTURE OF MAMMALIAN PEPTIDE TRANSPORTERS

FUNCTIONAL CHARACTERIZATION BY IN VITRO EXPRESSION

Substrate Specificity $\quad 8$

The role of protons in the transport of peptides $\quad 10$

Factors that influence transporter activity 11

DISTRIBUTION OF THE PEPTIDE TRANSPORTERS 13

DIETARY REGULATION OF PEPTIDE TRANSPORTERS 17

CHAPTER III. TISSUE DISTRIBUTION OF A PEPTIDE TRANSPORTER MRNA IN SHEEP, DAIRY COWS, PIGS, AND CHICKENS 20

ABSTRACT $\quad 20$

INTRODUCTION $\quad 22$

MATERIALS AND METHODS 23

$\begin{array}{ll}\text { Animals and tissue preparation } & 23\end{array}$

Preparation of total RNA and poly (A) ${ }^{+}$RNA 25

Cloning of a partial cDNA encoding ovine PepT1 26

$\begin{array}{ll}\text { Northern blot analysis } & 27\end{array}$

RESULTS 28

Cloning of a partial cDNA encoding a sheep peptide transporter 28

Tissue distribution of peptide transporter mRNA 29

DISCUSSION $\quad 30$

IMPLICATIONS

CHAPTER IV. EPILOGUE

LITERATURE CITED 49

VITA $\quad 57$ 


\section{LIST OF TABLES}

\section{TABLE}

3.1 Densitometric analysis of northern blots from sheep and dairy cows 36

3.2 Densitometric analysis of northern blots from pigs

3.3 Densitometric analysis of northern blots from chickens 


\section{LIST OF FIGURES}

\section{FIGURE}

2.1 Putative structure of the peptide transporter protein (PepT1)

3.1 Nucleic acid and amino acid sequences of the cDNA fragment (446 bp) cloned from sheep omasal epithelium.

3.2 Comparison of the amino acid sequence of the sheep cDNA fragment of peptide transporter with other published sequences.

3.3 Tissue distribution of peptide transporter mRNA in sheep.

3.4 Tissue distribution of peptide transporter mRNA in dairy cows.

3.5 Tissue distribution of peptide transporter mRNA in pigs.

3.6 Tissue distribution of peptide transporter mRNA in chickens. 


\section{Chapter I \\ INTRODUCTION}

Major efforts have been applied to the study of peptide absorption in the gastrointestinal tract, kidney (Daniel, 1996), liver, and skeletal muscle (Lochs et al., 1988). It is established that peptide transport is an important physiological process that occurs in tissues of animals (Matthews, 1991; Leibach and Ganapathy, 1996).

Recently, by the application of molecular techniques, several peptide transporters have been identified in mammals and these are categorized into two major groups, PepT1 and PepT2 (Fei et al., 1994; Liang et al., 1995; Miyomoto et al., 1996). The peptide transporter PepT1 is mainly expressed in the small intestine with much lower expression in liver, kidney, and some other tissues (Fei et al., 1994; Liang et al., 1995; Miyomoto et al., 1996). PepT2, on the other hand, is mainly expressed in kidney (Saito et al., 1996). The predicted protein structure of these transporters has 12 transmembrane domains and a very large extracellular loop between transmembrane domains IX and X (Fei et al., 1994; Meredith and Boyd, 1995). The amino acid sequences of the 12 transmembrane domains are highly conserved but the sequences of the extracellular loop are less conserved (Daniel, 1996). These peptide transporters appear to be able to transport most di- and tripeptide substrates, including some peptidomimetics, although their preference for zwitterionic or charged substrates may vary (Amasheh et al., 1997; Steel et al., 1997).

Results from studies conducted in our laboratory indicate the existence of a peptide transporter(s) in the forestomach of sheep (Matthews et al., 1996; Pan et al., 1997). Expression of mRNA in Xenopus oocytes showed that mRNA is present in sheep omasal epithelial tissue encoding for a peptide transporter(s) capable of transporting di- 
to tetrapeptides. Results from other studies from our laboratory indicate that peptide transport might be important in other tissues as well. Cultured mammary explants from mice and cultured bovine mammary gland epithelial cells (MAC-T), as well as rat myogenic cells $\left(\mathrm{C}_{2} \mathrm{C}_{12}\right)$ and ovine myogenic satellite cells have the ability to utilize exogenous methionine-containing peptides as sources for their methionine needs (Pan et al., 1996; Wang et al., 1996; Pan and Webb, 1998).

With the application of molecular cloning, defined RNA purification procedures, and northern blot analysis, the present study was designed to further verify the existence of the peptide transporter mRNA in the sheep forestomach and to survey the distribution of the peptide transporter mRNA in other tissues in sheep, dairy cows, pigs, and chickens. 


\section{Chapter II}

\section{REVIEW OF LITERATURE}

The importance of peptide transport has been documented in recent years. By taking advantage of molecular technology, a few peptide transporters have been identified. By cloning and in vitro expression, the molecular structures of these peptide transporters and the mechanisms by which the systems work have been revealed. This review will concentrate on recent efforts to characterize the peptide transporters and their functions.

\section{Molecular Cloning and Structure of Mammalian Peptide Transporters}

It was not until mid 1990's that the structures of the peptide transporters became clear. In 1994, two groups simultaneously reported the identification of a rabbit oligopeptide transporter named PepT1 (Fei et al., 1994; Boll et al., 1994). This was the beginning of a new era of peptide transport studies. The two groups used the same strategy starting from the isolation of poly(A) ${ }^{+}$RNA from the rabbit small intestinal epithelium. After size fractionation of the poly $(\mathrm{A})^{+}$RNA, a RNA pool for cDNA library construction was obtained. The constructed cDNA library contained messages from 2.2 to $5.0 \mathrm{~kb}$ in size. The cRNAs of the cDNA library were synthesized in vitro and injected into individual Xenopus laevis oocytes. Positive clones were detected by the ability for the injected oocytes to uptake radiolabeled peptide substrates (Gly-Sar or peptidomimetics cefadroxil). The full-length cDNA was isolated and sequenced. Analyzing the nucleic acid sequences of the peptide transporter allows the amino acid sequences to be determined and further predictions on the structures to be produced. 
The reported size of rabbit PepT1 cDNA is $2.7 \mathrm{~kb}$ (Fei et al., 1994). It has a single consensus polyadenylation site (AATAAA) that is 15 nucleotides upstream from the poly(A) tail and an open reading frame from nucleotides 31 to 2151 that codes for a protein consisting of 707-amino-acid residues. The amino acid sequence indicates that PepT1 is a membrane protein with 12 membrane-spanning domains. The protein has a large hydrophilic loop between domains IX and $\mathrm{X}$ and this makes the protein different from transporters reported previously. Based on the information from in vitro translation, this loop is the target for N-linked glycosylation and the authors believe it to be an extracellular portion of the protein. Other features, including a protein kinase $\mathrm{C}$ site and a cAMP-dependent phosphorylation site, appear also to be present on the protein (Figure 2.1).

Taking advantage of the published sequence for rabbit PepT1, others cloned human (Liang et al., 1995) and rat (Saito et al., 1995) PepT1. Human PepT1 was identified by screening a human intestinal cDNA library. The probe used for screening was a radiolabeled DNA fragment (600 bp) arising from rabbit PepT1 (Liang et al., 1995). At the same time, Saito et al. (1995) designed a series of primers based upon the sequence of rabbit PepT1. Using these primers for reverse transcription coupled polymerase chain reaction (RT-PCR), they obtained a $380 \mathrm{bp}$ PCR product as the probe and screened a rat kidney cDNA library. Therefore, both human and rat PepT1 were cloned based on the information provided by the sequence of rabbit PepT1.

Human PepT1 cDNA is $2.2 \mathrm{~kb}$ long with an open reading frame encoding for a protein composed of 708 amino acids (Liang et al., 1995). The open reading frame is flanked by a 56-bp long sequence on the 5' end and by an 80-bp long sequence on the 3' 
end. The translation start codon matches the Kozak consensus sequence (GCCGCCATGG). There appear to be two potential protein kinase C-dependent phosphorylation sites but no site for protein kinase A phosphorylation on this protein.

Rat PepT1 cDNA is 2.9 to $3.0 \mathrm{~kb}$ long with an open reading frame encoding a 710 amino acid protein (Saito et al., 1995; Miyamoto et al., 1996). The open reading frame was determined by a stop codon and a Kozak consensus initiation sequence (GCC(A/G)CAATGG). Sites for protein kinase A and protein kinase C phosphorylation were also reported.

Despite the different sizes of the PepT1 cDNA of these species obtained by the different groups, they all encode proteins that are very similar in structure. The 12 putative transmembrane domains and the long hydrophilic segment between domains IX and $\mathrm{X}$ are the most significant features for this group of transport proteins. The predicted structural model shows a long hydrophilic loop on the extracellular side containing several $N$-linked glycosylation sites. With all the $12 \alpha$-helices accommodated on the membrane, both the amino and carboxyl termini are located on the cytoplasmic side. These PepT1 proteins are highly homologous. The amino acid sequence of the rat PepT1 is $77 \%$ and $83 \%$ identical with the rabbit and human PepT1, respectively (Saito et al., 1995). The rabbit and human PepT1 are $81 \%$ identical (Liang et al., 1995). The amino acid sequences of these transporters do not show strong homology with other known classes of transport proteins. It is worth mentioning that all of the transmembrane domains are highly conserved, whereas the extracellular loop is much less conserved. Structural differences among these transport proteins indicate that there are different 
numbers and locations of sites for protein kinase $\mathrm{A}$ and $\mathrm{C}$ phosphorylation. The extent to which these differences may affect the function of the transporters is still not clear.

When using a 560 bp DNA fragment from rabbit PepT1 to screen a human kidney cDNA library, Liu et al. (1995) identified another peptide transporter (PepT2) that was proved to be structurally and functionally different from PepT1. Following up in 1996, rat and rabbit PepT2 were also cloned by two groups (Boll et al., 1996; Saito et al., 1996).

The human full-length PepT2 cDNA is $2.7 \mathrm{~kb}$ with an open reading frame of 2.2 $\mathrm{kb}$ (Liu et al., 1995). The coding sequence is flanked by a 30 bp sequence on the 5' end and a 465 bp sequence on the 3' end with the start codon matching the Kozak consensus sequence. The predicted protein contains 729 amino acids with 12 transmembrane domains and a long hydrophilic segment between transmembrane domains IX and X. There are also several $\mathrm{N}$-glycosylation sites and sites for protein kinase C-dependent phosphorylation. The rat PepT2 cDNA is $3.9 \mathrm{~kb}$ with an open reading frame designated by a stop codon and a Kozak consensus sequence (Saito et al., 1996). Although the sizes of these PepT2 cDNAs are different, they all encode a 729 amino acid protein (Boll et al., 1996). The shared features include the putative 12 transmembrane domains, the large extracellular loop, and several sites for protein kinase dependent phosphorylation.

These structural features are observed in both the PepT1 and PepT2 transporter groups. Even with these similarities, these are two distinct transporter groups. When PepT1 and PepT2 are compared from the same species, they display lower identity than do the members in the same group. For example, human PepT2 has $83 \%$ amino acid identity with rat PepT2 whereas only 50\% with human PepT1. PepT2 proteins have 
more molecular mass than PepT1. Other differences including tissue distribution and functional characteristics will be discussed later.

Dantzig et al. (1994) reported finding a distinct peptide transporter (HPT-1) in human intestinal cells. The HPT-1 was identified by screening a Caco- 2 cell cDNA library with a monoclonal antibody to the transporter protein. The cloned cDNA is 3.3 $\mathrm{kb}$ and contains a $2.5 \mathrm{~kb}$ open reading frame that encodes for an 832 amino acid protein. The predicted amino acid sequence suggests the presence of only one transmembrane domain. This significant structural difference likely affects the mechanism by which this protein transports peptides. Little information is available on the relationship between HPT-1 and PepT1 or PepT2.

Recently, Yamashita et al. (1997) reported the results of a study on a brain peptide/histidine transporter (PHT1) cloned from rat brain. They developed a probe based on the sequence of the rabbit PepT1. A brain cDNA library was screened using the radiolabeled probe and the positive clone was identified and sequenced. The cloned rat PHT1 cDNA is $2.7 \mathrm{~kb}$ and has an open reading frame flanked by a 24-bp sequence at the 5' end and a 1,008-bp sequence at the 3' end. The predicted protein is composed of 572 amino acids. Although PHT1 has 12 transmembrane domains, it is much shorter than either PepT1 or PepT2. Most significantly, PHT1 does not have a large extracellular loop between any transmembrane domains. The PHT1 has only $17 \%$ identity with PepT1 and $12 \%$ identity with PepT2. All of these features, along with its distinct tissue distribution, provide convincing evidence suggesting that PHT1 probably represents a new family of mammalian peptide transporters. 


\section{Functional Characterization by In Vitro Expression}

Transport activity of these cloned peptide transporters has been characterized mainly by in vitro expression of the cDNA in Xenopus laevis oocytes or other cell lines. The Xenopus oocyte is a well-defined experimental model that is extensively used for in vitro expression. The oocytes have the ability to accept foreign messenger RNA and later translate it into functional proteins. The biochemical and physiological properties of the proteins can then be studied through the functional examination of the synthesized proteins in Xenopus oocytes.

Substrate Specificity. Transport studies have shown that the cloned peptide transporters are capable of uptaking a broad range of di- and tripeptides and peptidomimetics. Peptides are transported, regardless of whether they contain acidic, basic, or hydrophobic amino acids. The peptides transported are either charged or neutral under different conditions.

In order to study the effects of the net charge of a substrate on peptide transport and reduce the structural difference, four dipeptides were used as substrates to examine uptake by small intestinal tissue (Lister et al., 1997). The dipeptides used included PheGlu, Phe-Lys, Phe-Gln, and Phe-Ala. The four hydrolysis resistant dipeptides were perfused through an isolated loop of rat small intestine. The absorbed peptides were analyzed by HPLC. The results showed that, at pH 7.5, two charged dipeptides (Phe-Glu, -1 , and Phe-Lys, +1) were transported slower than the neutral dipeptides (Phe-Gln and Phe-Ala). When the $\mathrm{pH}$ was lowered to 6.8 , transport rate for the negatively charged Phe-Glu and the neutral peptides (Phe-Gln and Phe-Ala) increased whereas transport rate for the positively charged Phe-Lys decreased. Increasing the $\mathrm{pH}$ to 8.0 strongly inhibited 
the uptake of the neutral peptide Phe-Ala but increased the uptake for Phe-Lys. The results suggest that neutral substrates are preferred by the peptide transporter when compared with charged peptides under physiological $\mathrm{pH}$ conditions.

Substrate specificity of rabbit PepT1 was studied by examining the uptake of charged or neutral glycyl dipeptides by Xenopus oocytes injected with rabbit PepT1 cRNA (Amasheh et al. 1997). A radioactive marker, ${ }^{3} \mathrm{H}-\mathrm{Phe}-\mathrm{Ala}$, was used for the study. The uptake of differently charged substrates was determined by measuring the inhibition of ${ }^{3} \mathrm{H}$-Phe-Ala uptake upon addition of substrates at $\mathrm{pH}$ of 8.0, 7.4, 6.5, and 5.5. More inhibition means more absorption of the substrate by the transporter. The glycyl peptides studied included Gly-Gln (zwitterionic), Gly-Asp (anionic), and Gly-Lys (cationic). At each $\mathrm{pH}$, Gly-Gln strongly inhibited the uptake of ${ }^{3} \mathrm{H}-\mathrm{Phe}-\mathrm{Ala}$. The Gly-Asp inhibited the uptake of ${ }^{3} \mathrm{H}$-Phe-Ala at a $\mathrm{pH}$ of 7.4 or lower. Gly-Lys inhibited uptake only when the $\mathrm{pH}$ was at or higher than 6.5. The authors suggest that, under physiological conditions, the affinity of the PepT1 for the zwitterionic or anionic substrates is greater than for cationic substrates. For transport of a cationic substrate, the $\mathrm{pH}$ must be higher.

Results from the examination of the transport of the anionic cefixime and zwitterionic cefadroxil in Xenopus oocytes expressing rabbit PepT1 and in Caco-2 cells have been reported (Wenzel et al., 1996). In both oocytes and Caco- 2 cells, zwitterionic cefadroxil was transported more rapidly at a $\mathrm{pH}$ equal or higher than 6.0. The anionic cefixime was absorbed more efficiently when the $\mathrm{pH}$ was equal to or lower than 6.0 (Wenzel et al., 1996). The authors calculated the percentage of the charged or zwitterionic forms of the substrates at each $\mathrm{pH}$. For instance, the relative proportion of the neutral form of cefixime increased as the $\mathrm{pH}$ was lowered below 6.0. These results 
again indicate that the zwitterionic form of the substrate is preferred by the peptide transporters under physiological conditions.

In a study conducted by Ganapathy et al. (1997), the peptidomimetics cephalosporins (cefixime, ceftibuten, and cefdinir) were used as the substrates to study substrate interactions with PepT1 and PepT2. At their experimental $\mathrm{pH}$ of 6.0 , cefixime and ceftibuten were dianionic and cefdinir was monoanionic. The human intestinal cell line, Caco-2, which only expresses PepT1 (Ganapathy et al., 1995) and rat kidney cell line, SKPT, which only expresses PepT2 (Brandsch et al., 1995) were used. Uptake of ${ }^{14} \mathrm{C}-$ Gly-Sar in both cell lines was inhibited significantly by cephalosporins in the order of ceftibuten> cefixime> cefdinir. The same results were obtained when PepT1 and PepT2 were expressed in Hela cells. In a subsequent study, Xenopus laevis oocytes injected with PepT1 and incubated with the negatively charged ceftibuten at $\mathrm{pH} 7.5$, showed a tiny outward current. At pH 6.0, addition of ceftibuten (dianionic) to the buffer induced a huge inward current. These results provide further evidence that the zwitterion is the preferred form.

The Role of Protons in the Transport of Peptides. One of the features of peptide transporters is the necessity for the proteins to cotransport a proton along with the peptide substrate. Brandisch et al. (1997) studied the effect of protons on the affinity and $\mathrm{V}_{\max }$ of Gly-Sar uptake by Caco-2 (PepT1) and SKPT cells (PepT2). Uptake of Gly-Sar was measured over a concentration range in both cells at an outside $\mathrm{pH}$ of either 6.0 or 7.0. In Caco-2 cells, the $\mathrm{K}_{\mathrm{t}}$ was $1.0 \mathrm{mM}$ at $\mathrm{pH} 6.0$ and $1.2 \mathrm{mM}$ at $\mathrm{pH} 7.0$. However, the $\mathrm{V}_{\max }$ was $13.7 \pm 0.3 \mathrm{nmol} \cdot 10 \mathrm{~min}^{-1} \cdot \mathrm{mg}^{-1}$ of protein at $\mathrm{pH} 6.0$ and $5.8 \pm 0.3 \mathrm{nmol} \cdot 10 \mathrm{~min}^{-1} \cdot \mathrm{mg}^{-1}$ of protein at $\mathrm{pH}$ 7.0. Similar results were obtained with SKPT cells. In both cell types, 
protons affected only $\mathrm{V}_{\max }$ but did not affect the affinity of the transporters for the substrates.

Steel et al. (1997) expressed PepT1 in Xenopus oocytes to study the stoichiometry and $\mathrm{pH}$ dependency of PepT1. They observed a reduction of the $\mathrm{pH}$ inside the cell when differently charged peptides (Gly-Glu, Gly-Leu, and Gly-Lys) were transported, suggesting the movement of protons. After calculating the rate at which different dipeptides induced intracellular acidification and the rate of the uptake of peptides and the related charge influxes, the authors suggested a proton-peptide coupling ratio of $1: 1$, 2:1, and 1:1 for neutral, acidic, and basic dipeptides, respectively. The results also indicated that at a $\mathrm{pH}$ of 5.5 to 6.0, PepT1 favored substrates in neutral and acidic forms.

It has been suggested for several ion-coupled solute transporters, such as $\mathrm{Na}^{+} /$glucose cotransporter, that binding and dissociation of ions near the extracellular surface of the transporter evokes a pre-steady-state current that results in a conformational change and leads to a translocation of the charged empty carrier (Mackenzie et al., 1996). However, Nussberger et al. (1997) used voltage clamp techniques to address this issue in a proton/peptide cotransporter. Their results indicated a symmetry of $\mathrm{H}^{+}$binding in response to either intra- or extracellular acidification. They concluded that PepT1 has only one proton binding site that can be accessed from either side of the membrane.

Factors that Influence Transporter Activity. Given the role of these proteins as peptide transporters, factors that influence the protein structure, its localization on the membrane, and the specific position for substrate binding may all have an effect on the transport activity. Histidyl residues are critical in several proton coupled transporter 
systems such as the $\mathrm{Na}^{+} / \mathrm{H}^{+}$exchanger. Diethyl pyrocarbonate (DEPC) can chemically modify the histidyl residues, making them incapable of being a proton donor or an acceptor. In 1997, Brandsch et al. treated both Caco-2 and SKPT cells with DEPC and examined the uptake of radiolabeled Gly-Sar by these cells. Uptake by these DEPCtreated cells was significantly decreased as compared with the control cells. At the same time, Fei et al. (1997) identified three conserved histidyl residues in both hPepT1 (His57, His-121, and His-260) and hPepT2 (His-87, His-142, and His-278). Site directed mutagenesis was used to mutate the histidine codon (CAT or CAC) to an asparagine (AAT or AAC) or glutamine codon (CAA). The mutants were expressed in both oocytes and HeLa cells. Transport activity was examined by the measurement of uptake of GlySar. Results showed mutations of His-121 and His-260 in PepT1, and His-142 and His278 in PepT2 did not affect the uptake of Gly-Sar. On the other hand, the PepT1 with mutated His-57 and PepT2 with mutated His-87 failed to show any uptake of the substrate. The data clearly indicate that His-57 in PepT1 and His-87 in PepT2 are the most critical histidyl residues necessary for the uptake function.

Previous studies have shown the presence of sites on the peptide transporters for protein kinase C- and A-dependent phosphorylation. Since cAMP can activate protein kinase $\mathrm{C}$ and $\mathrm{A}$ in the cAMP pathway, increasing cAMP via the addition of cholera toxin will increase the activity of protein kinases C and A. Muller et al. (1996) used this method to increase the intracellular levels of cAMP in Caco-2 cells that expressed PepT1. Results showed that the ability of these cells to uptake Gly-Sar decreased by $50 \%$. It may be that protein kinases $\mathrm{C}$ and $\mathrm{A}$ are involved in the regulation of peptide transport. 
Zinc is an essential trace element that has many fundamental roles including structural motif, part of an enzyme, and regulatory factors. Daniel and Adibi (1995) used kidney brush border membrane vesicles (BBMV) to investigate the hypothesis that zinc may be involved in the process of peptide transport. Results showed that the incubation of BBMV with zinc sulfate increased the uptake of Gly-Gln, Leu-Tyr, and cephalexin by two-fold without changing diffusion rate of the substrates. Zinc had no effect on the uptake of either Gln or glucose by BBMV. Therefore, the authors concluded that zinc had a selective effect on peptide transport.

More recently, Doring et al. (1997) performed a functional analysis of peptide transport by using a chimeric transporter obtained from the intestinal and renal isoforms. The chimeric peptide transporter (CH1Pep) was constructed in such a way that the amino terminus (residues 1-401) was from PepT2, while the carboxy terminus (402-707) was from PepT1. The function of CH1Pep was studied in oocytes. Results showed that CH1Pep had all the functional characteristics of PepT2 including the high affinity, the substrate specificity, and the dependence on $\mathrm{pH}$. This indicated that the phenotype of PepT2 is determined by its amino terminus.

\section{Distribution of the Peptide Transporters}

Information of the distribution of the peptide transporters among various tissues comes largely from the search for the messenger RNA that encodes for the protein. Along with the cloning of PepT1 and PepT2 from various species, the distributions of their mRNA have been studied. The basic technique is northern blot analysis using a specific radiolabeled DNA probe. For most studies reported, full-length cDNA were used as the probes for northern blot analysis. 
By using PepT1 full-length cDNA as the probe for northern blot analysis, a $2.9 \mathrm{~kb}$ mRNA was found in the small intestine of the rabbit and much lower levels were observed in the liver and kidney and only trace amounts were found in the brain (Fei et al., 1994). No mRNA was detected in the colon, skeletal muscle, heart, spleen, or lung. The mRNA for PepT1 was 2.9 to $3.0 \mathrm{~kb}$ in the rat and the major location of this mRNA was in the small intestine (Saito et al., 1995; Miyamoto et al., 1996). Trace amounts of mRNA were found in kidney cortex but none was observed in liver. Human PepT1 mRNA is $3.3 \mathrm{~kb}$ based on northern blot analysis (Liang et al., 1995). They observed a major presence of this PepT1 mRNA in the small intestine as well as in an intestinal epithelium derived cell line (Caco-2). They also observed PepT1 mRNA in kidney, placenta, liver, and pancreas. The mRNA transcript was absent in muscle, brain, and heart.

The mRNA of peptide transporter PepT2, on the other hand, has a different pattern of distribution. When the full-length cDNA of PepT2 was used for northern blot analysis in rat, a $4 \mathrm{~kb}$ mRNA was found mainly in the kidney medulla and at lower abundance in the kidney cortex (Saito et al., 1996). The mRNA was also detected in brain, lung, and spleen, but was undetectable in the heart, liver, and small intestine. In the rabbit, when a complementary RNA fragment synthesized from PepT2 cDNA (1.24 $\mathrm{kb}$ ) was used as the probe, a $4.8 \mathrm{~kb}$ mRNA was found in the kidney cortex as well as in brain, lung, liver, and heart (Boll et al., 1996). Northern blot analysis of PepT2 mRNA from human tissues with PepT2 cDNA as the probe resulted in no detectable hybridization (Liu et al., 1995). By using RT-PCR, the mRNA was detected in human kidney and small intestine (Liu et al., 1995). 
There is some variation in results of northern blot analysis in some tissues among the animals tested, especially in tissues that have a minor expression of peptide transporter mRNA. This may come from the application of slightly different approaches by different groups. This could cause different sensitivities in northern blot analysis. On the other hand, different animals may display different patterns of peptide transporter mRNA distribution.

Using in situ hybridization, cellular expression of PepT1 mRNA along the rabbit gastrointestinal tract was studied (Freeman et al., 1995a). Two anti-sense oligonucleotides (45 nucleotides) were radiolabeled as the probes for in situ hybridization. The entire GI tract tissues were frozen and sectioned. The tissue sections were fixed onto glass slides and hybridized with the radiolabeled probes. The autoradiographs showed that the mRNA was expressed all along the small intestine and reduced its level dramatically in the colon. PepT1 mRNA was not detected in the stomach, sacculus rotundus, or cecum. These results are in agreement with the northern blot analysis of rabbit intestine (Fei et al., 1994). In addition, results of the in situ hybridization demonstrated that the expression was restricted to the epithelial surface of the small intestine and there was no detectable expression in deeper tissues such as the lamina propria, muscularis mucosa, or serosa. Along the crypt-villus axis, the mRNA was detected at or above the crypt-villus junction with the maximal expression occurring at about 100 to $200 \mu \mathrm{m}$ above the junction. The mRNA was absent in the lower to mid crypt in the entire small intestine. This expression pattern of PepT1 mRNA along the crypt-villus was similar to some villus-specific proteins, such as sodium-glucose cotransporter (SGLT1) and the plasma membrane calcium pump (PMCA1, Freeman et 
al., 1993, 1995b). It has been suggested that the existence of some common regulatory factors that act on promoter regions of genes expressed specifically on the villus may be the cause of this pattern of gene expression (Freeman, 1995). Therefore, the corresponding protein expression at the same time or a little bit later would be expected. The reason why there are needs for such specific expressions of these genes is still unknown.

Ogihara et al. (1996) were the first to investigate the localization of the transporter protein itself instead of its mRNA. They developed an anti-PepT1 antibody and used it to conduct immunoblotting for the examination of the PepT1 protein in rat. Their results confirmed the exclusive expression of PepT1 in the small intestine and the absence of PepT1 in the crypt. They also found that PepT1 was specific to the differentiated absorptive epithelial cells and was located mainly on the brush border membrane of the cell.

From these results we can conclude that PepT1 and PepT2 are distributed differently among tissues. PepT1 is mainly an intestinal peptide transporter whereas PepT2 is mainly a renal peptide transporter. Interestingly, PepT1 is also detectable in the kidney. The existence of PepT1 in the small intestine of animals is nutritionally as well as pharmacologically important. The transport of peptides contributes to the body nitrogen needs (Matthews, 1991). It may even serve as a pathway for the absorption of some metals that are required by the animal (Tacnet et al., 1993). The peptide transport system also participates in the transport of many therapeutically active peptides, such as some orally administrated drugs, including peptide-like antibiotics, anti-cancer drugs (Inui et al., 1992), and angiotensin-converting enzyme inhibitors (Swaan et al., 1995). 
The PepT2 in the kidney may also play a significant role in conserving peptide forms of amino nitrogen by means of reabsorption (Daniel and Herget, 1997). The existence and function of the peptide transporter in other tissues is not clear. It is suggested that the peptide transporter in brain may help with the uptake of bioactive peptides and later facilitate the removal of excess neuropeptides. Although it is considered that liver does not take up peptides from the circulation, heterogeneous cells that liver contains other than its own hepatocytes may have peptide transport activity. Therefore, some liver samples may express positive results in northern analysis for peptide transporter mRNA.

\section{Dietary Regulation of Peptide Transporters}

How dietary factors affect the status and function of the peptide transporters and, therefore, how dietary factors regulate the activity of the transporters so that animals can be better nourished is of interest to nutritionists. The effect of different dietary protein levels on the expression of PepT1 was studied by examining mRNA expression along the longitudinal axis of rat small intestine (Erickson et al., 1995). Northern blot analysis of mRNA from the intestine of rats on a normal diet (17\% casein) showed that mRNA for PepT1 $(3.0 \mathrm{~kb})$ was relatively evenly distributed along the longitudinal axis of the small intestine. Changing the diet from low (4\% casein) to high (50\% gelatin) protein resulted in a 1.5- to 2-fold increase in the PepT1 mRNA level in the middle and distal small intestine. The authors concluded that dietary protein levels have a regulatory effect on the expression of the peptide transporters, at least as indicated by the relative abundance of their mRNA. The results from this study also indicated that the distal part of the small intestine of the rat was the primary site for the adaptive response. 
How dietary proteins regulate these peptide transporters and whether the regulatory effects are at the gene expression level or whether they regulate the structure and function of the protein are yet to be determined. Further studies on the relationship between gene expression and the structure and function of the transporters are needed. 


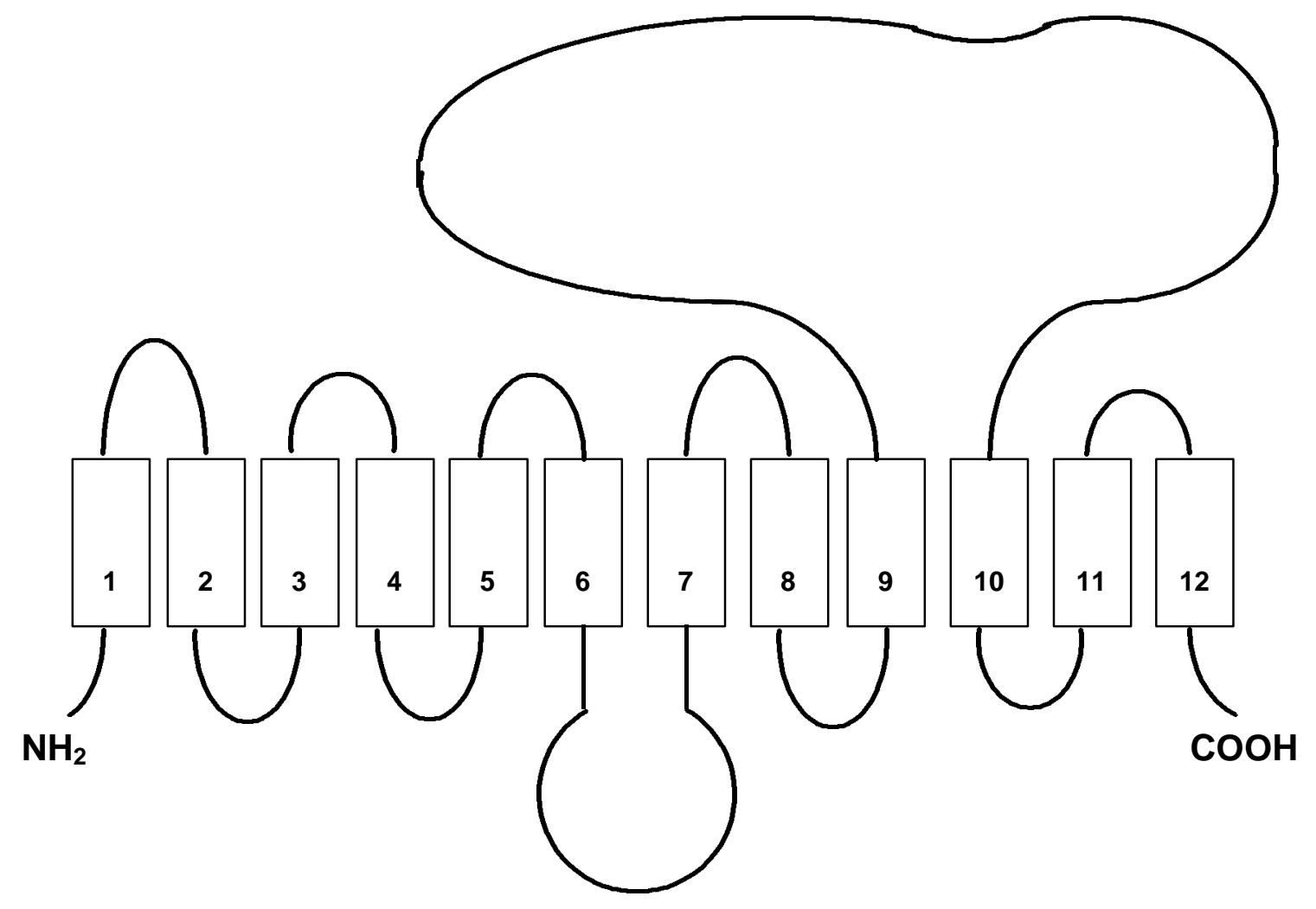

Figure 2.1. The putative structure of peptide transporter (PepT1, Fei et al., 1994).

Numbered boxes indicate the twelve transmembrane domains. 


\title{
Chapter III
}

\section{TISSUE DISTRIBUTION OF A PEPTIDE TRANSPORTER mRNA IN SHEEP, DAIRY COWS, PIGS, AND CHICKENS}

\begin{abstract}
To study the mRNA found in sheep omasal epithelium encoding for a peptide transport protein(s), a 446-bp cDNA fragment was cloned from sheep omasal epithelium RNA. The predicted amino acid sequence of this fragment was $85.8,90.5$, and 90.5 percent identical to rabbit, human, and rat PepT1, respectively. The fragment was radiolabeled for use as a probe to study the distribution of the mRNA in various tissues. Total RNA was extracted and mRNA was isolated from the epithelium of gastrointestinal segments and other tissues as indicated. Northern blot analysis was conducted using the radiolabeled probe. In sheep (5) and lactating Holstein cows (3), hybridization was observed with mRNA from the omasum, rumen, duodenum, jejunum, and ileum. The estimated size of mRNA was $2.8 \mathrm{~kb}$. No hybridization was observed with mRNA from the abomasum, cecum, colon, liver, kidney, and semitendinosus and longissimus muscles of either species or the mammary gland of the dairy cows. In pigs (6), the probe hybridized with mRNA from the duodenum, jejunum, and ileum. There was no hybridization with mRNA from the stomach, large intestine, liver, kidney, and semitendinosus and longissimus muscles. Two bands, 3.5 and $2.9 \mathrm{~kb}$ were observed with northern blot analysis, indicating two RNA transcripts that may result from alternative mRNA processing. In both Leghorns (15) and broilers (20), the strongest hybridization was found in the duodenum while the jejunum and ileum showed faint bands. The size of mRNA in chickens was $1.9 \mathrm{~kb}$. Other tissues, including the crop, proventriculus, gizzard,
\end{abstract}


ceca, liver, kidney, and muscles showed no hybridization to the probe. In conclusion, mRNA for a peptide transport protein(s) is present in the small intestine of all animals examined and the omasal and ruminal epithelium of sheep and dairy cows. The size of the mRNA varied among species.

Key Words: Peptide transporter, PepT1, Tissue, Messenger RNA, Intestine 


\section{Introduction}

The existence of a transport process for intact peptides through mammalian intestinal and renal epithelial membranes has been recognized for several years and the importance of the peptide transporter has been well-documented (Matthews, 1991; Leibach and Ganapathy, 1996). Only recently has the presence of peptide transporters been identified in mammals by the application of molecular techniques (Fei et al., 1994; Liang et al., 1995; Miyomoto et al., 1996). The identified mammalian peptide transporters are divided into two major groups, PepT1 and PepT2. The predicted protein structure of these peptide transporters has 12 transmembrane domains and a very large extracellular loop between transmembrane domains IX and X (Fei et al., 1994; Meredith and Boyd, 1995). The amino acid sequences of the 12 transmembrane domains are highly conserved, but the sequences of the extracellular loop are less conserved (Daniel, 1996). These peptide transporters appear to be able to transport most di- and tripeptide substrates, including some peptidomimetics, although their preference for zwitterionic or charged substrates may vary (Amasheh et al., 1997; Steel et al., 1997). The peptide transporter PepT1 is mainly expressed in the small intestine with much lower expression in liver, kidney, and some other tissues (Fei et al., 1994; Liang et al., 1995; Miyomoto et al., 1996). The PepT2, on the other hand, is mainly expressed in kidney (Saito et al., 1996).

Studies from our laboratory have shown the existence of a peptide transporter(s) in the forestomach of sheep (Matthews et al., 1996; Pan et al., 1997). Translation of mRNA in Xenopus oocytes showed that the mRNA is present in sheep omasal epithelial 
tissue encoding for a peptide transporter(s) capable of transporting di- to tetrapeptides.

Results from other studies from our laboratory indicated that peptide transport might be important in other tissues as well. Cultured mammary explants from mice and cultured bovine mammary gland epithelial cells (MAC-T), as well as rat myogenic cells $\left(\mathrm{C}_{2} \mathrm{C}_{12}\right)$ and ovine myogenic satellite cells have the ability to utilize exogenous methioninecontaining peptides as sources for their methionine needs (Pan et al., 1996; Wang et al., 1996; Pan and Webb, 1998). The present study was designed to further verify the existence of the peptide transporter mRNA in the sheep forestomach and to survey the distribution of the peptide transporter mRNA in other tissues in sheep, dairy cows, pigs, and chickens.

\section{Materials and Methods}

Animals and Tissue Preparation. The protocols followed were reviewed and approved by the Virginia Tech Animal Care Committee. A total of five yearling crossbred sheep, three primiparous lactating Holstein cows, six crossbred pigs (8 wk of age), one group of broilers (5 wk of age), and two groups of Leghorns (14 wk of age) were used in the experiment. The sheep (average BW $62.8 \mathrm{~kg}$ ) were stunned by a captive bolt pistol and killed by exsanguination. The rumen and omasum were removed and washed with ice-cold $.9 \%$ saline. Ruminal epithelium was peeled from underlying and connective tissues. Individual omasal plies were removed. The fundic region of the abomasum and intestinal sections, including the duodenum, jejunum, ileum, cecum, and colon, were washed with ice-cold $.9 \%$ saline and the epithelium was scraped using a glass slide. The duodenal tissue collected was the first $1 \mathrm{~m}$ of small intestine beginning at the pyloric sphincter. The ileal tissue was the $1 \mathrm{~m}$ distal portion of the small intestine that 
ended at the ileocecocolic junction. About $1 \mathrm{~m}$ from the middle of the small intestine was taken as the jejunal tissue. The colon and cecum were taken starting from the ileocecocolic junction. Samples of liver, kidney, semitendinosus, and longissimus muscle were also removed. All of the tissues and scrapings were quickly frozen in liquid $\mathrm{N}$ and later transferred to $-80^{\circ} \mathrm{C}$ for storage. The dairy cows (average $382 \mathrm{~d}$ in milk and $31.9 \mathrm{~kg} / \mathrm{d}$ of milk yield) were killed following the same procedure as used with the sheep. Stomach, intestinal sections, liver, kidney, semitendinosus, and longissimus muscles were collected and stored as described for the sheep. In addition, mammary tissue from the right rear quarter was collected and stored. The pigs (average BW $18.0 \mathrm{~kg}$ ) were killed by intravenous injection of sodium pentobarbital. The stomach and intestinal sections, including the duodenum, jejunum, ileum, cecum, and colon, were collected and processed as described for the sheep. Likewise, liver, kidney, semitendinosus, and longissimus muscles were quickly removed and sampled. Broilers (average BW $1.63 \mathrm{~kg}$ ) and Leghorns (average BW $1.96 \mathrm{~kg}$ ) were killed by cervical dislocation. The gastrointestinal tract, liver, kidney and samples of fibularis longus and pectoralis muscles were quickly removed. Gastrointestinal segments were cleaned by rinsing with ice-cold $.9 \%$ saline. The epithelial lining was peeled off from the crop, proventreculus, and gizzard and saved. The proximal enlarged loop of the small intestine was taken as the duodenum. The rest of the small intestine was divided by Meckel's diverticulum into upper and lower portions and correspond to the jejunum and ileum, respectively. The ceca were also sampled. The epithelium from the intestinal segments was scraped using a glass slide. All the collected tissues and scrapings were quickly frozen in liquid $\mathrm{N}$ and transferred to $-80^{\circ} \mathrm{C}$ for storage. Prior to the extraction of total RNA, composites of individual tissues 
were formed. Tissues from the 20 broilers were combined and the tissues from the Leghorns were combined to produce two samples, one contained tissues from seven and the other contained tissues from eight birds.

Preparation of Total RNA and Poly $(A)^{+}$RNA. Total RNA was extracted from the tissues using the method described by Puissant and Houdebine (1990). Tissue was homogenized in a solution containing $4 M$ guanidine thiocyanate, $25 \mathrm{~m} M$ sodium citrate, $110 \mathrm{~m} M \beta$-mercaptoethanol, and .5\% N-laurylsarcosinate. Then, $2 M$ acetic acid (pH 4.0), water-saturated phenol ( $\mathrm{pH} 4.1$ ), and chloroform were sequentially added to the homogenate and mixed well. The mixture was centrifuged at $12,000 \times g$ at $4^{\circ} \mathrm{C}$ for 20 min. The top layer was transferred to a new bottle and precipitated with an equal volume of isopropanol at $-20^{\circ} \mathrm{C}$ overnight. After centrifugation at $4,000 \times g$ at $4{ }^{\circ} \mathrm{C}$ for $20 \mathrm{~min}$, the pellet was washed with $4 \mathrm{M} \mathrm{LiCl}$ and centrifuged at $4,000 \times g$ for $20 \mathrm{~min}$. The pellet was then dissolved in a buffer of $10 \mathrm{~m} M$ Tris- $\mathrm{HCl}(\mathrm{pH}$ 7.6), $1 \mathrm{~m} M$ EDTA, and $.5 \%$ sodium lauryl sulfate (SDS). The RNA solution was mixed with an equal volume of chloroform and centrifuged at $12,000 \times g$ at $4^{\circ} \mathrm{C}$ for $20 \mathrm{~min}$. The upper phase containing total RNA was transferred to a new tube and precipitated with .1 volume of $3 M$ sodium acetate ( $\mathrm{pH} 5.0)$ and an equal volume of isopropanol at $-20^{\circ} \mathrm{C}$ overnight. The precipitate was centrifuged at $12,000 \times g$ at $4^{\circ} \mathrm{C}$ for $20 \mathrm{~min}$. Total RNA was recovered by dissolving the pellet in diethyl pyrocarbonate (DEPC)-treated water. The absorbance was measured at both 260 and $280 \mathrm{~nm}$ to determine RNA content and purity. The integrity of total RNA was checked indirectly by examining the integrity of ribosomal RNA after RNA electrophoresis and ethidium bromide staining. 
Poly $(\mathrm{A})^{+}$RNA was isolated from total RNA using oligo(dT) cellulose (Sambrook et al., 1989). Approximately $150 \mathrm{mg}$ of oligo(dT) cellulose was used to make one column (at a volume of approximate $1 \mathrm{~mL}$ ). The column was regenerated by washing with $.1 \mathrm{~N} \mathrm{NaOH}$ and then neutralized to less than $\mathrm{pH} 8.0$ with column loading buffer containing $20 \mathrm{~m} M$ Tris- $\mathrm{HCl}(\mathrm{pH} 7.6), 1 \mathrm{~m} M$ EDTA, $.5 \mathrm{M} \mathrm{NaCl}$, and $.1 \% \mathrm{~N}$ laurylsarcosinate. Typically, 4 to $5 \mathrm{mg}$ of total RNA were loaded per column. After washing with column loading buffer to eliminate non-specific binding, the column was eluted with $10 \mathrm{~m} M$ Tris- $\mathrm{HCl}\left(\mathrm{pH}\right.$ 7.6) and $1 \mathrm{~m} M$ EDTA. The poly(A) ${ }^{+}$RNA was precipitated with .1 volume of $3 M$ sodium acetate (pH 5.0) and 1 volume of isopropanol at $-20^{\circ} \mathrm{C}$ overnight. The precipitate was centrifuged at $12,000 \times g$ for $20 \mathrm{~min}$, and the poly $(\mathrm{A})^{+}$RNA was recovered by dissolving the pellet in DEPC-treated water and stored at $-80^{\circ} \mathrm{C}$ for future use.

Cloning of a Partial cDNA Encoding Ovine PepT1. Primers (IDT, Coraville, IA) for reverse transcription coupled polymerase chain reaction (RT-PCR) were designed based on a comparison of published nucleic acid sequences of rabbit, human, and rat PepT1. The primer for RT was: TTA GCC CAG TCC AGC CAG AG (corresponding to nucleotides 808-827 in rabbit PepT1). The two primers for polymerase chain reaction (PCR) were: TGG CTG GG(G/A) AAG TTC AAG AC (corresponding to nucleotides 259-278 in rabbit PepT1) and CTT CTT GTA CAT (C/T)CC ACT GC (corresponding to nucleotides 686-705 in rabbit PepT1). Total RNA (10 $\mu \mathrm{g})$ from sheep omasal epithelium was added to $40 \mathrm{ng}$ of primer at $37^{\circ} \mathrm{C}$ and boiled for $2 \mathrm{~min}$. The cDNA was synthesized with moloney murine leukemia virus (M-MLV) reverse transcriptase (Life Technologies, Gaithersburg, MD). After purification of the product using Sephadex G-25 
chromatography and ethanol precipitation, the RT product was used as the template for PCR. The PCR was performed with a set of primers $(.5 \mu M) 35$ cycles of: $94^{\circ} \mathrm{C}$ for 1.5 $\min , 57^{\circ} \mathrm{C}$ for $2 \mathrm{~min}, 72^{\circ} \mathrm{C}$ for $1.5 \mathrm{~min}$. The PCR products were separated on a $1 \%$ agarose gel and a fragment of the expected size was purified using glassmilk (Bio101, La Jolla, CA). The product was treated with T4 DNA polymerase to remove overhanging ends left by Taq polymerase, ligated into SmaI cut plasmid pTZ18R (Pharmacia Biotech, Piscataway, NJ), and transformed into Escherichia coli competent cells (strain 71-18). Clones containing the correct insert were screened by cutting the plasmids with endonucleases EcoRI and HindIII. The cloned fragment was then sequenced by the dideoxy chain-termination method using the Sequenase version 2.0 DNA sequencing kit (United States Biochemical, Cleveland, OH). The confirmed fragment (446 bp) was used as a probe for northern blot analysis.

Northern Blot Analysis. Thirty micrograms of total RNA or $10 \mu \mathrm{g}$ poly(A) ${ }^{+}$RNA from each tissue were electrophoresed through $1 \%$ agarose gel containing $2.2 \mathrm{M}$ formaldehyde and stained with ethidium bromide. The RNA was transferred to a nylon membrane (MSI, Westboro, MA) by capillary transfer and cross-linked with UV light. Blots were probed with the sheep peptide transporter cDNA fragment excised from pTZ18R by BamHI and HindIII digestion. The probe was purified by Glassmilk and labeled with $\left[\alpha-{ }^{32} \mathrm{P}\right] \mathrm{dATP}$ (ICN Pharmaceuticals, Costa Mesa, CA) by nick translation using DNA polymerase I/DNase I (Life Technologies, Gaithersburg, MD). Blots were prehybridized for 1 to $2 \mathrm{~h}$ at $42^{\circ} \mathrm{C}$ in hybridization solution containing $50 \%$ deionized formamide, $5 \times$ Denhardt's solution, $6 \times$ saline-sodium phosphate-EDTA (SSPE), $.2 \%$ SDS, and $10 \mu \mathrm{g} / \mathrm{ml}$ yeast tRNA. Following the addition of the labeled probe at $7 \mathrm{ng}$ 
$\mathrm{DNA} / \mathrm{mL}$ hybridization solution, hybridization was conducted at $42^{\circ} \mathrm{C}$ for 12 to $18 \mathrm{~h}$. Blots were washed under high stringency conditions with: $5 \times$ SSPE, $.5 \%$ SDS at room temperature; $1 \times \mathrm{SSPE}, .5 \% \mathrm{SDS}$ at $37^{\circ} \mathrm{C}$; and $.1 \times \mathrm{SSPE}, 1 \% \mathrm{SDS}$ at $65^{\circ} \mathrm{C}$. The blots were exposed to Kodak XAR-5 film with intensifying screens at $-80^{\circ} \mathrm{C}$.

The size of the mRNA bands was determined with an RNA marker (.24 to $9.5 \mathrm{~kb}$. Life Technologies, Gaithersburg, MD). The bands on northern blots were quantified using a laser densitometer (Molecular Dynamics, Mitsubishi, Japan). Arbitrary densitometric units (ADU) were determined for each band. Because the northern blots were conducted for every tissue of a given animal on the same blot, a relative comparison of RNA expression among tissues could be determined. The relative densitometric unit (RDU) for the jejunum of a given animal was set as 1.0 and RDU of other tissues of the same animal were calculated by comparison of the ADU with the ADU for the jejunum.

\section{Results}

Cloning of a Partial cDNA Encoding a Sheep Peptide Transporter. Based on previous studies from our laboratory, a peptide transport protein(s) capable of transporting peptides up to four amino acids in length is present in sheep omasal epithelium (Matthews et al., 1996; Pan et al., 1997). Therefore, sheep omasal epithelium mRNA was used as the template for RT-PCR to develop a probe for northern blot analysis. The published sequences of rabbit, human, and rat PepT1 (Fei et al., 1994; Liang et al., 1995; Miyamoto et al., 1996) were used to design oligonucleotides to a highly homologous region (from transmembrane domain III to VI). After RT-PCR amplification, a 446-bp fragment from sheep omasal epithelium was cloned (Figure 3.1). 
The predicted amino acid sequence of this fragment was $85.8,90.5$, and 90.5 percent identical to rabbit, human, and rat PepT1, respectively (Figure 3.2).

Tissue Distribution of Peptide Transporter mRNA. For sheep and dairy cows, mRNA from the rumen, omasum, and small intestine showed positive hybridization in northern blot analysis (Figures 3.3 and 3.4). The size of the mRNA that hybridized to our probe was $2.8 \mathrm{~kb}$ for both sheep and dairy cows. From the summary of the northern blot analysis for the five sheep and three cows tested, the patterns for the expression appeared to be consistent within the same species although the relative levels of expression varied among animals (Table 3.1). Among these tissues, mRNA from the jejunum and ileum showed the most extensive hybridization with the radiolabeled probe and mRNA from the omasum and duodenum showed less hybridization. The mRNA from the rumen showed only minimal hybridization indicating that this mRNA was present in low abundance. The other tissues, including the abomasum, liver, kidney, cecum, colon, longissimus, and semitendinosus muscles, and mammary gland in dairy cows, did not show hybridization with the probe in northern blots analysis. Hybridization of the probe to $28 \mathrm{~S}$ ribosomal RNA in some tissues was likely the result of non-specific hybridization.

In pigs, hybridization of mRNA to the probe was found only in the small intestine. No hybridization was found in any other tissues examined (Figure 3.5). Interestingly, there were two bands, 2.9 and $3.5 \mathrm{~kb}$, found in the northern blots of swine small intestine. With the exception of one pig the relative distribution of the mRNA for the peptide transporter among the intestinal segments was remarkably consistent among pigs (Table 3.2). Expression of the peptide transporter mRNA in five of the six pigs was 
highest in the jejunum followed by the duodenum. One pig showed the most hybridization in the duodenum. The least hybridization was found in the ileum of the pigs.

In chickens, only the mRNA from the small intestinal region showed hybridization with our probe (Figure 3.6). The size of the mRNA that hybridized with the probe in the small intestine of the chickens was $1.9 \mathrm{~kb}$. The extent of hybridization to the probe was greatest in the duodenum (Table 3.3). The magnitude of the hybridization of mRNA from the jejunum and ileum to the probe was about a third and a fourth, respectively, that observed in the duodenum. The mRNA from the preintestinal regions of the gastrointestinal tract, including the crop, proventreculus, and gizzard, as well as the mRNA from the ceca, did not show any hybridization with the probe. No hybridization with the probe was detected from mRNA from liver and kidney, or from the fibularis longus and pectoralis muscles.

\section{Discussion}

The recent cloning and characterization of both intestinal (PepT1) and renal (PepT2) peptide transporters from different species has provided strong evidence of the importance of the peptide transport system to mammalian species. The unique structural and functional features shared by these peptide transport proteins have prompted considerable interest in examining these systems. Northern blot analysis using the fulllength PepT1 cDNA as the probe revealed a $2.9 \mathrm{~kb}$ mRNA for rabbit and rat PepT1 and a 3.3 kb mRNA for human PepT1 in the small intestine (Fei et al., 1994; Liang et al., 1995; Saito et al., 1995; Miyamoto et al., 1996). 
In the present experiments, a $2.8 \mathrm{~kb}$ mRNA from the small intestine of both sheep and dairy cows, 3.5 and $2.9 \mathrm{~kb}$ mRNA from swine small intestine, and a $1.9 \mathrm{~kb}$ mRNA from chicken small intestine hybridized to our ovine probe in northern blot analysis. This indicates that a peptide transporter mRNA exists in the small intestine of all these animals. The distribution of mRNA along the small intestine was not the same among species. The duodenum, jejunum, and jejunum and ileum appeared to be the primary sites of the mRNA for the peptide transporter in chickens, pigs, and ruminants, respectively. Assuming that the relative presence of mRNA is indicative of expression of the transport protein, it may be concluded that the extent of peptide transport is also variable along the length of the small intestine. The differences among species may reflect the site of protein digestion and the availability of peptide substrates. The major site of amino acid absorption is recognized to be the jejunum in laboratory species such as the rat (Baker and George, 1971) and the ileum in sheep (Phillips et al., 1976, 1979) and cattle (Wilson and Webb, 1990).

In addition to the intestine, the rumen and omasum are sites of considerable absorptive activity in ruminants. Experiments conducted in our laboratory have provided evidence that intact dipeptides can be transferred across the omasal and ruminal epithelial tissues (Matthews and Webb, 1995). Expression of peptide transport capability by Xenopus laevis oocytes injected with mRNA from sheep omasal epithelium provided further evidence that peptide transport occurs in the ruminant stomach (Matthews et al., 1996; Pan et al., 1997). Results from the present study indicate that the ruminal and omasal epithelium of sheep and dairy cows have a $2.8 \mathrm{~kb}$ mRNA that encodes for a peptide transport protein. The hybridization of the probe with the mRNA from the 
omasal epithelium was much stronger than with mRNA from the ruminal epithelium in both sheep and dairy cows. Matthews et al. (1996) also reported higher absorptive activity of substrate peptides in the omasum than in the rumen. Both of these areas of the ruminant stomach are recognized for their capabilities to absorb large quantities of VFA. Prior to the results of research from our laboratory indicating that peptides may be absorbed from the rumen and omasum, ammonia was the only end product of protein digestion recognized as being absorbed to any significant extent from the ruminant stomach.

Reports from others have shown the presence of mRNA for PepT1 at very low levels in the liver and kidney of the rabbit and human (Fei et al., 1994; Liang et al., 1995). Miyamoto et al. (1996) also reported detectable bands of mRNA from kidney in rat but they did not detect any hybridization to their probe with liver mRNA. In the present study, we were unable to detect any hybridization on northern blots to our probe with mRNA in the liver or kidney in any of the animals we examined. That our observations differed from previous reports could be due to the different probe we used. Our probe was only a partial cDNA to PepT1. Lower expression of the peptide transporter mRNA in the liver and kidney may not have been detectable in our system due to reduced sensitivity of the partial cDNA probe. Alternatively, our results may indicate a different pattern of expression for the peptide transporter mRNA in these commonly raised farm animals. Saito et al. (1995) reported their observations on the tissue distribution of PepT1 in rat. Like in our studies, in their northern blot analysis using the full-length rat PepT1 cDNA as the probe, the $2.9 \mathrm{~kb}$ mRNA was detected only in the small intestine. 
In previous studies from our laboratory, bovine mammary epithelial cells (MAC-T) and rat myogenic cells $\left(\mathrm{C}_{2} \mathrm{C}_{12}\right.$; Pan et al., 1996), ovine myogenic satellite cells (Pan and Webb, 1998), and cultured mouse mammary explants (Wang et al., 1996) were studied for their ability to utilize exogenous methionine-containing peptides as methionine sources. The results showed that all of these cells and the explants had the ability to utilize exogenous methionine-containing peptides as sources of methionine for protein synthesis. With the cultured cells and explants, there was evidence that transport of the peptide into the cells was occurring, indicating the possible presence of one or more peptide transport protein(s). When we screened for the presence of a mRNA for a peptide transporter in muscle and mammary gland tissues, we did not detect any hybridization to our probe by mRNA in these tissues. One explanation for the results may be that the methionine-containing peptides previously observed to be utilized by cultured cells and explants enter cells via mechanisms other than peptide transporters. On the other hand, there may be a peptide transporter(s) present other than the one that will hybridize with our probe. The probe we used likely did not allow us the ability to detect the existence of other peptide transporter mRNA even though they may exist and have important physiological functions. To date, no detectable PepT1 mRNA in muscles has been reported in any animal examined (Fei et al., 1994; Liang et al., 1995; Miyamoto et al., 1996). The present study provides the only examination of the mammary gland of which we are aware.

Recently, the cloning of a rat brain peptide transporter (PHT1) was reported (Yamashita et al., 1997). The predicted protein has 572 amino acid residues and it is the smallest peptide transporter cloned so far in animals. This much smaller protein lacks the 
large extracellular loop predicted for the other peptide transporters reported. The lack of the extracellular loop appeared to have no effect on the absorptive function of the protein. Expression of PHT1 in Xenopus laevis oocytes induced a $\mathrm{H}^{+}$-dependent histidine, di-, and tripeptide transport. Even though the size of the protein was small, northern blot analysis revealed a $2.9 \mathrm{~kb}$ mRNA which was present mainly in brain tissue. To date, the mRNA we identified in the chicken small intestine is the smallest peptide transporter mRNA reported. The size of the mRNA that hybridized to our probe was only $1.9 \mathrm{~kb}$. This probably indicates that the chicken peptide transport protein in the small intestine is quite small. It will be interesting to further investigate the protein encoded by the $1.9 \mathrm{~kb}$ mRNA and study its functional characteristics. It may be that the protein is quite different from other species, or it may be that the smaller size of the mRNA is associated with the absence of certain less or nonessential portions of the protein. There is some similarity between chicken mRNA and sheep mRNA because our probe was cloned from sheep omasal mRNA and it hybridized to chicken intestinal mRNA under high stringency conditions.

In conclusion, the cDNA probe we developed from sheep omasal epithelium was able to detect the presence of mRNA in all the animals we examined. The mRNA may encode a peptide transport protein(s). From the northern blot results, hybridization was observed in the small intestinal region in all the animals examined and in omasal and ruminal epithelium of sheep and dairy cows. The size of the mRNA varied among species. It was $2.8 \mathrm{~kb}$ in sheep and dairy cows; there were two bands, 3.5 and $2.9 \mathrm{~kb}$, detected in pigs; and the mRNA in chickens was only $1.9 \mathrm{~kb}$. Thus, peptide absorption 
from the gastrointestinal tract appears to be a physiologically relevant process in all the species examined.

\section{Implications}

The present study provides important information on the general tissue distribution of the mRNA of a peptide transporter in several farm animals. These results will contribute to the cloning and further characterization of the peptide transporter(s) in these animals. The application of molecular techniques to the study of mechanisms of the peptide transport system in these farm animals will reveal the nutritional significance of this biological process. The knowledge gained will lead to the better management of the nutritional needs of these animals and minimize the environmental contamination by wasted $\mathrm{N}$ at the same time. 
Table 3.1. Densitometric analysis of northern blots from sheep and dairy cows.

\begin{tabular}{|c|c|c|c|c|c|c|c|c|c|c|c|c|c|}
\hline \multirow[b]{2}{*}{ Animal } & \multicolumn{13}{|c|}{ Tissues (RDU) ${ }^{a}$} \\
\hline & $\mathrm{SM}^{\mathrm{b}}$ & LM & $\mathrm{K}$ & $\mathrm{L}$ & $M$ & $\mathrm{O}$ & $\mathrm{R}$ & $A$ & $D$ & $J$ & I & $\mathrm{Ce}$ & Co \\
\hline Sheep 1 & $-c$ & - & - & - & & - & - & - & .35 & 1.0 & 1.96 & - & - \\
\hline Sheep 2 & - & - & - & - & & .26 & .42 & - & .29 & 1.0 & 8.60 & - & - \\
\hline Sheep 3 & - & - & - & - & & .17 & .07 & - & .22 & 1.0 & .81 & - & - \\
\hline Sheep 4 & - & - & - & - & & .72 & .14 & - & .34 & 1.0 & 18.96 & - & - \\
\hline Sheep 5 & - & - & - & - & & .06 & .02 & - & .22 & 1.0 & .52 & - & - \\
\hline Cow 1 & - & - & - & - & - & .02 & .02 & - & .21 & 1.0 & .69 & - & - \\
\hline Cow 2 & - & - & - & - & - & 2.47 & 1.17 & - & .71 & 1.0 & 6.18 & - & - \\
\hline Cow 3 & - & - & - & - & - & .35 & .17 & - & .28 & 1.0 & 1.18 & - & - \\
\hline
\end{tabular}

${ }^{\mathrm{a}}$ Relative densitometric units (RDU) for the jejunum is set as 1.0 and RDU for other tissues are calculated by comparing the arbitrary densitometric units (ADU) to the ADU for the jejunum for a given animal.

${ }^{\mathrm{b}} \mathrm{SM}$ : semitendinosus muscle; LM: longissimus muscle; K: kidney; L: liver; M:

mammary gland; O: omasum; R: rumen; A: abomasum; D: duodenum; J: jejunum; I:

ileum; Ce: cecum; Co: colon.

${ }^{\mathrm{c}}$ The tissues showing no hybridization are marked as “_.“. 
Table 3.2. Densitometric analysis of northern blots from pigs.

\begin{tabular}{lcccccccccc}
\hline & \multicolumn{10}{c}{ Tissues (RDU) $^{a}$} \\
\cline { 2 - 10 } Animal & SM $^{\mathrm{b}}$ & LM & $\mathrm{K}$ & $\mathrm{L}$ & $\mathrm{S}$ & $\mathrm{D}$ & $\mathrm{J}$ & $\mathrm{I}$ & $\mathrm{Ce}$ & Co \\
\hline Pig 1 & $-{ }^{\mathrm{c}}$ & - & - & - & - & $.69^{\mathrm{d}}$ & 1.0 & .42 & - & - \\
Pig 2 & - & - & - & - & - & 2.90 & 1.0 & .34 & - & - \\
Pig 3 & - & - & - & - & - & .65 & 1.0 & .34 & - & - \\
Pig 4 & - & - & - & - & - & .62 & 1.0 & .34 & - & - \\
Pig 5 & - & - & - & - & - & .54 & 1.0 & .51 & - & - \\
Pig 6 & - & - & - & - & - & .54 & 1.0 & .32 & - & - \\
\hline
\end{tabular}

${ }^{\mathrm{a}}$ Relative densitometric units (RDU) for the jejunum is set as 1.0 and RDU for other tissues are calculated by normalizing the arbitrary densitometric units (ADU) to the ADU for the jejunum for a given animal.

${ }^{\mathrm{b}} \mathrm{SM}$ : semitendinosus muscle; LM: longissimus muscle; K: kidney; L: liver; S: stomach; D: duodenum; J: jejunum; I: ileum; Ce: cecum; Co: colon.

${ }^{\mathrm{c}}$ The tissues showing no hybridization are marked as “_.".

${ }^{\mathrm{d}}$ The $2.9 \mathrm{~kb}$ bands are scanned by the densitometer and the ADU and corresponding RDU are calculated. 
Table 3.3. Densitometric analysis of northern blots from chickens.

\begin{tabular}{|c|c|c|c|c|c|c|c|c|c|c|c|}
\hline \multirow[b]{2}{*}{ Animal $^{b}$} & \multicolumn{11}{|c|}{ Tissues (RDU) ${ }^{a}$} \\
\hline & $\operatorname{LM}^{\mathrm{c}}$ & $\mathrm{BM}$ & $\mathrm{K}$ & $\mathrm{L}$ & $\mathrm{Cr}$ & $\mathrm{Gi}$ & $\mathrm{Pr}$ & $D$ & $J$ & I & $\mathrm{Ce}$ \\
\hline Broilers & $-d$ & - & - & - & - & - & - & 2.28 & 1.0 & .60 & - \\
\hline Leghorns 1 & - & - & - & - & - & - & - & 3.98 & 1.0 & .64 & - \\
\hline Leghorns 2 & - & - & - & - & - & - & - & 3.12 & 1.0 & .94 & - \\
\hline
\end{tabular}

${ }^{a}$ Relative densitometric units (RDU) for the jejunum is set as 1.0 and RDU for other tissues are calculated by normalizing the arbitrary densitometric units (ADU) to the ADU for jejunum for a given animal.

${ }^{\mathrm{b}}$ Chickens were tested as groups. The group of broilers contained 20 broilers. Leghorns were divided into two groups. Group 1 contained seven Leghorns and group 2 contained eight.

${ }^{\mathrm{c}} \mathrm{LM}$ : fibularis longus muscle; BM: pectoralis muscle; K: kidney; L: liver; Cr: crop; Gi:

gizzard; Pr: proventreculus; D: duodenum; J: jejunum; I: ileum; Ce: cecum.

${ }^{\mathrm{d}}$ The tissues showing no hybridization are marked as “_.”. 


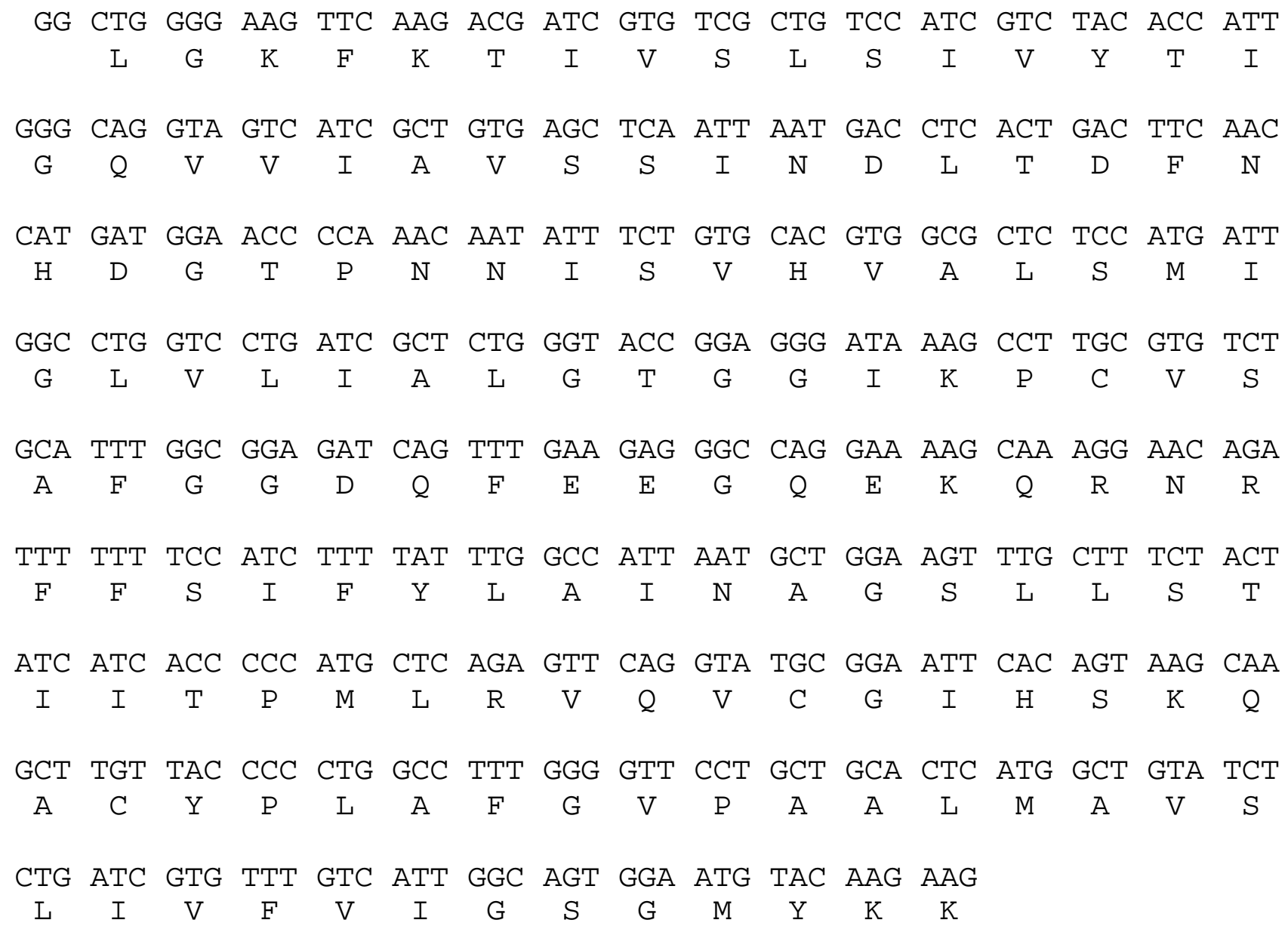

Figure 3.1. Nucleic acid and amino acid sequences of the cDNA fragment (446 bp) cloned from sheep omasal epithelium. 
Sheep LGKFKTIVSLSIVYTIGQVVIAVSSINDLTDFNHDGT

Rabbit --------W---------A-TSL--V-E---N-----

Human ------------------A-TS---------H-----

Rat - - - - -------------A--S---------HD---S

Sheep PNNISVDVALSMIGLVLIALGTGGIKPCVSAFGGDQF

Rabbit -DSLP----VC----L---------------------

Human -DSLP---V-- $\mathrm{L}---\mathrm{A}--------------------$

Rat --- LPL---------A---------------------

Sheep EEGQEKQRNRFFSIFYLAINAGSLLSTIITPMLRVQV

Rabbit --------------------------------V---Q

Human ------------------------------------Q

Rat - - - - - - - - - - - - - - - - - - - - - - - - - - $-\mathrm{I}----\mathrm{Q}$

Sheep CGIHSKQACYPLAFGVPAALMAVSLIVFVIGSGMYKK

Rabbit ----V----------I--I---------I-------

Human -----------------------A---- $-\mathrm{L}-------$

Rat - - - - Q-----------------A-----L-------

Figure 3.2. Comparison of the amino acid sequence of the sheep cDNA fragment of peptide transporter with other published sequences (rabbit, human, and rat PepT1).

Underlined sequences indicate transmembrane domains. 


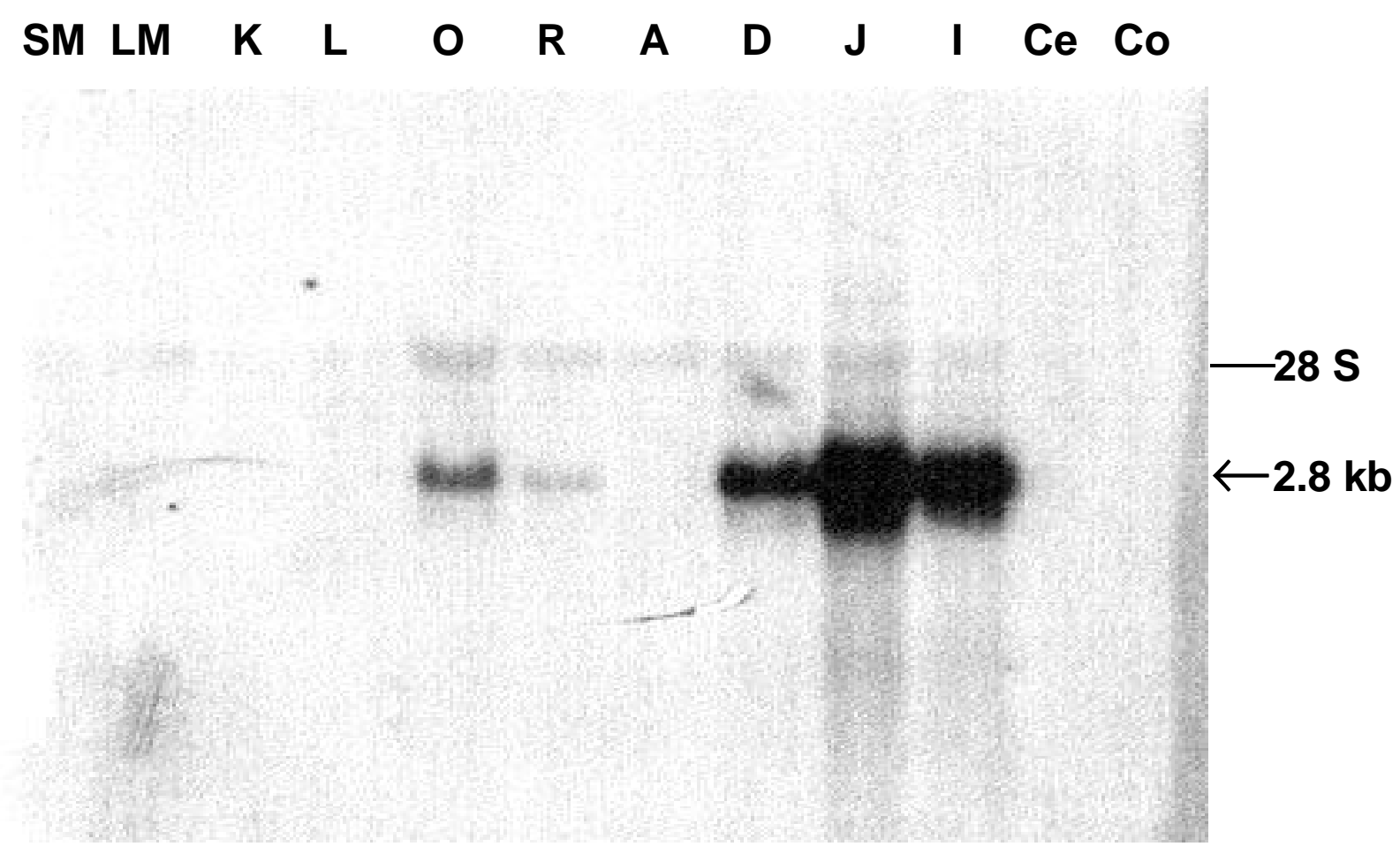

Figure 3.3. Tissue distribution of peptide transporter mRNA in sheep. SM:

semitendinosus muscle; LM: longissimus muscle; K: kidney; L: liver; O: omasum; R:

rumen; A: abomasum; D: duodenum; J: jejunum; I: ileum; Ce: cecum; Co: colon. $28 \mathrm{~S}$ indicates position of $28 \mathrm{~S}$ ribosomal RNA. 


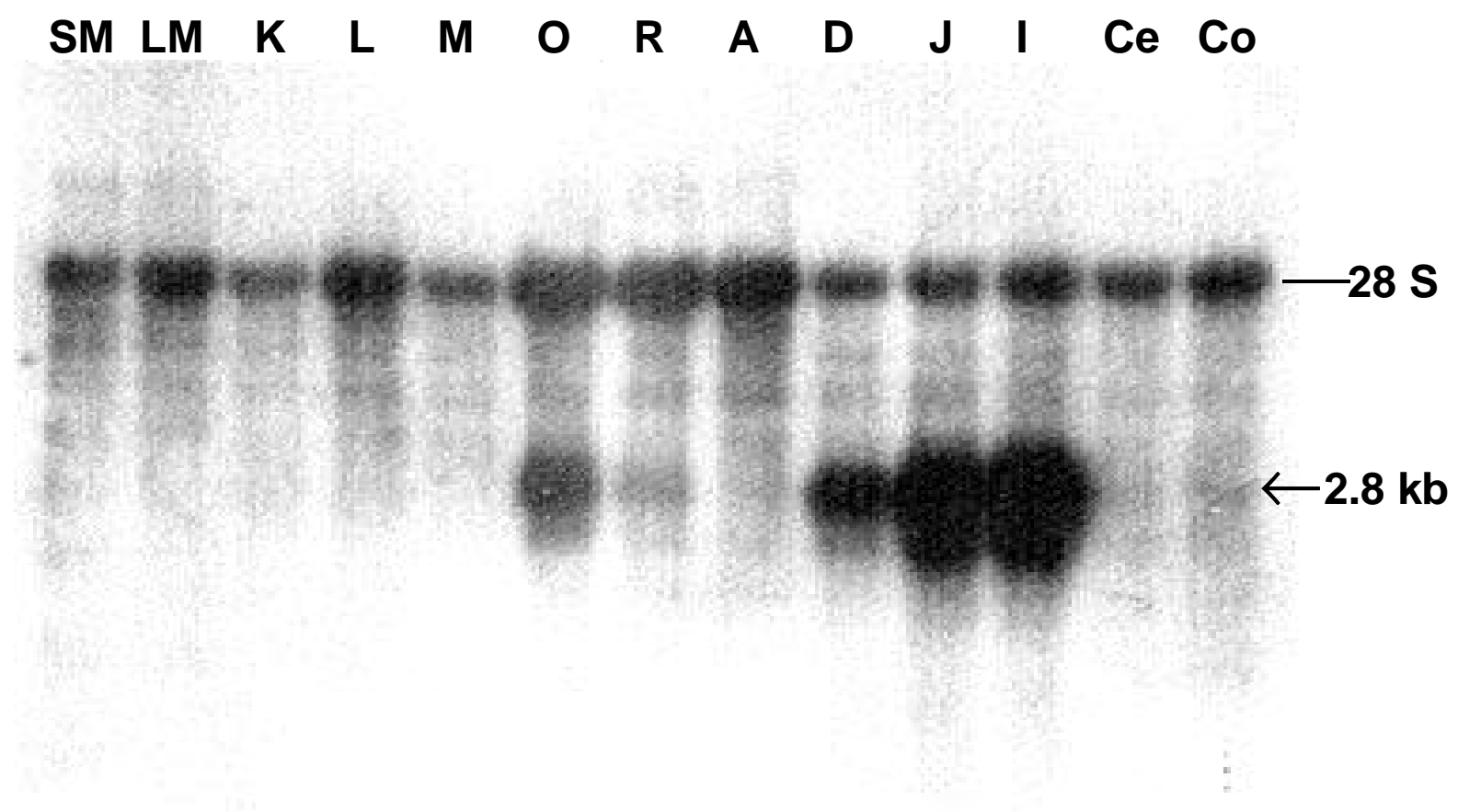

Figure 3.4. Tissue distribution of the peptide transporter mRNA in dairy cows. SM: semitendinosus muscle; LM: longissimus muscle; K: kidney; L: liver; M: mammary gland; O: omasum; R: rumen; A: abomasum; D: duodenum; J: jejunum; I: ileum; Ce: cecum; Co: colon. $28 \mathrm{~S}$ indicates position of $28 \mathrm{~S}$ ribosomal RNA. 


\section{$\begin{array}{lllllllllll}\text { SM } & \text { LM } & \text { K } & \text { L } & \text { S } & \text { D } & \text { J } & \text { I } & \text { Ce } & \text { Co }\end{array}$}

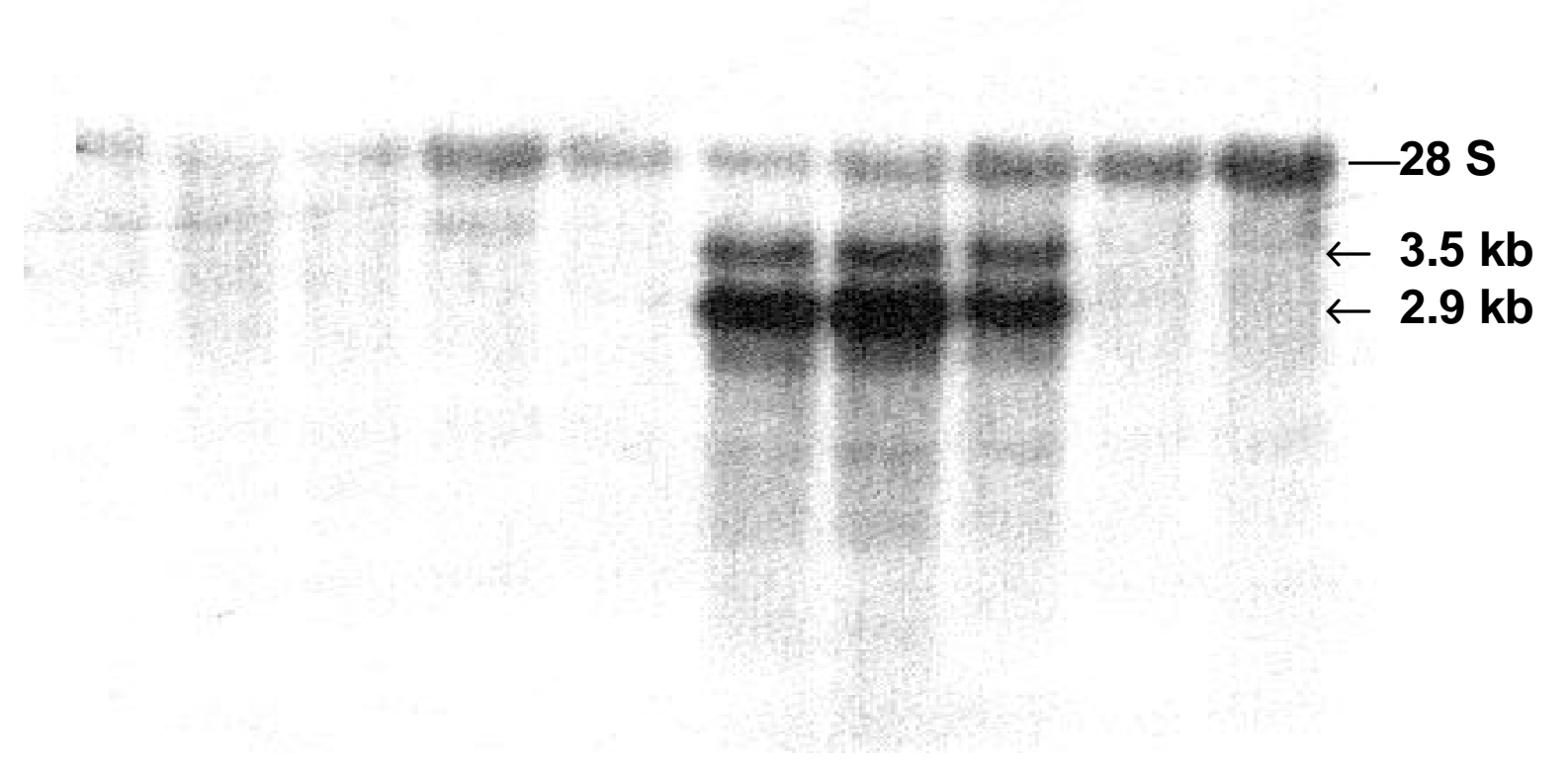

Figure 3.5. Tissue distribution of peptide transporter mRNA in pigs. SM: semitendinosus muscle; LM: longissimus muscle; K: kidney; L: liver; S: stomach; D: duodenum; J: jejunum; I: ileum; Ce: cecum; Co: colon. $28 \mathrm{~S}$ indicates position of $28 \mathrm{~S}$ ribosomal RNA. 


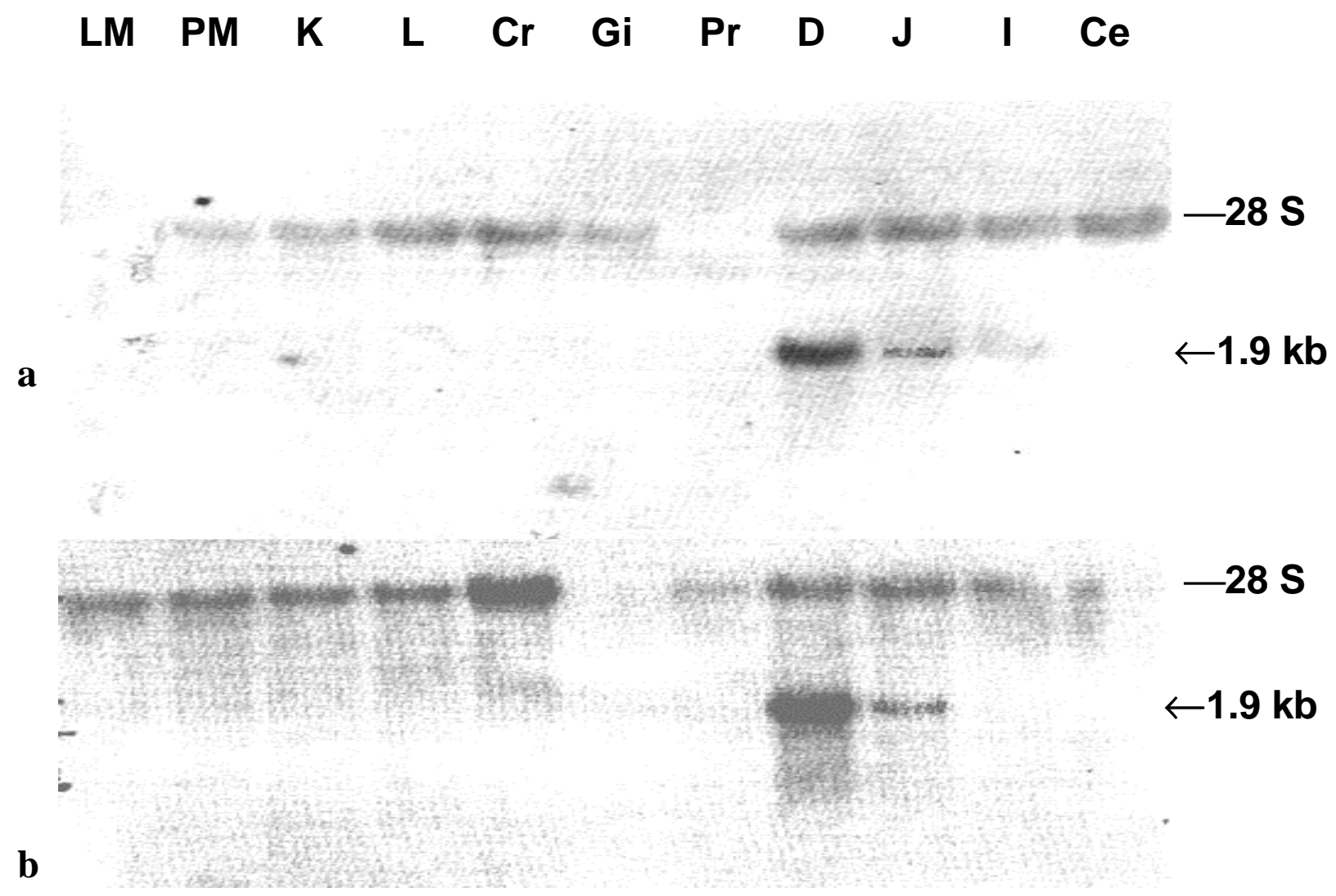

Figure 3.6. Tissue distribution of peptide transporter mRNA in chickens. LM: fibularis longus muscle; PM: pectoralis muscle; K: kidney; L: liver; Cr: crop; Gi: gizzard; Pr: proventreculus; D: duodenum; J: jejunum; I: ileum; Ce: cecum. a: northern blot results from broilers; b: northern blot results from Leghorns. $28 \mathrm{~S}$ indicates position of $28 \mathrm{~S}$ ribosomal RNA. 


\section{Chapter IV}

\section{EPILOGUE}

The present study provides strong evidence that a peptide transporter mRNA exists in the gastrointestinal tract of all the animals examined, and the distribution of this mRNA along the small intestine varies among species. The study proved that the cDNA probe developed from the sheep omasal epithelium can detect the peptide transporter mRNA from the gastrointestinal tract of all the animals examined. This being the case, it seems logical to conclude that peptide absorption from the gastrointestinal tract via a transport protein is a physiologically relevant process in all the species examined. Further confirmation and identification of the transporter(s) will be necessary in order to understand the function of the peptide transporters in these animals. One of the methods one might use for the identification of the transporter(s) is the molecular cloning of the gene for the protein. Cloning and further characterization of the peptide transporter(s) in the animals studied here are a bit closer to reality because of the results from the present study.

The construction of a cDNA library might be the next step leading to the cloning of the peptide transporter. The present study demonstrated that the peptide transporter mRNA was present mainly in the small intestine of all the animals examined. Individually speaking, the mRNA was found mainly in the ileum of sheep and dairy cows, the jejunum of pigs, and the duodenum of chickens. Therefore, cDNA libraries can be constructed accordingly to obtain the maximum abundance of the message for the peptide transporter for each species. The cDNA probe developed from sheep omasal epithelial RNA in the present study was used for the detection of the peptide transporter 
mRNA in all the species examined. The nucleotide sequence of this probe is very similar to sequences in several known intestinal peptide transporters (rabbit, human, and ratPepT1). Therefore, this cDNA probe can be used for the future screening of cDNA libraries from different species to isolate the peptide transporter message and to clone the whole gene for the peptide transporter. Having the cloned peptide transporter will provide significant opportunities to characterize and study the structure and function of the peptide transporter.

Although the present study demonstrated the tissue distribution of the mRNA of the peptide transporter, the presence and the distribution of the transporter protein still remains unknown. Therefore, studies of the distribution of the peptide transporter protein at tissue and cellular levels are necessary. With the cloning of the peptide transporter, development of anti-transporter antibodies will be applicable. Studies involving in situ hybridization and immunolocalization will provide even more information on the distribution and localization of the peptide transporter.

The determination of whether the transcription of the mRNA is regulated by the availability of peptide substrates to the transporter or by an internal factor(s) will provide insight into the regulation of the expression of the transporter. Results from the present study showed that, although the peptide transporter mRNA is detected through the entire small intestine of all the species examined, the relative abundance of the mRNA varies among the different parts of the small intestine from species to species. For instance, the mRNA was found to be mainly associated with the middle to lower part of small intestine of sheep and dairy cows and smaller amounts were observed in the proximal part of the small intestine. On the other hand, the greatest expression of the mRNA was found in the 
proximal and middle part of the small intestine in pigs as well as mainly the duodenum in chickens. Therefore, studies are needed for the investigation of the possible causes of the observed phenomenon. Identification of the promoter region for the transporter gene will facilitate the studies of the possible regulatory factors such as dietary factors or any other intrinsic factors.

In the future, the peptide transporter in pig needs to be further examined by cloning and sequencing the gene for the peptide transporter. There are two sizes of mRNA (2.9 and $3.5 \mathrm{~kb})$ reported in the present study to be present in the intestinal epithelium of pigs. In all the previous studies, only a single size of mRNA has been observed. It is not yet known whether there are actually two different peptide transporter mRNA in pigs that can be recognized by our probe or whether the peptide transporter mRNA in pigs is undergoing a special RNA processing that results in mRNA with two different sizes. Cloning and sequencing of the peptide transporter will provide more accurate information on the nature of these two sizes of transporter mRNA.

The peptide transporter mRNA detected in chickens in the present study was only $1.9 \mathrm{~kb}$. This is the smallest peptide transporter mRNA reported. Further study is needed to determine whether this is a different peptide transporter that exists in poultry rather than PepT1 identified in mammals. Apparently there are some similarities between chicken and sheep peptide transporter mRNA because the chicken peptide transporter mRNA hybridized to our probe under high stringency conditions. If they are the same peptide transporters, which part of the sequence is lacking in the chicken peptide transporter mRNA is a question that needs to be answered. The chicken peptide transporter protein translated from the mRNA is apparently going to be smaller. It may 
be that the chicken peptide transporter lacks the large extracellular loop found in intestinal and renal peptide transporters in mammals. Therefore, in the future, studies are needed to determine the structure of the chicken peptide transporter and to elucidate its function.

Finally, with the cloning of the peptide transporter in these animals, the whole cDNA sequence of the peptide transporter may be used as the probe for northern blot analysis. In previous studies, peptide transporter mRNA was found to be present in liver, kidney, and minor amounts were observed to in some other tissues of humans, rats, and rabbits (Fei et al., 1994; Liang et al., 1995; Boll et al., 1996; Yamashita et al., 1997). In the present study, peptide transporter mRNA was not detected in any other tissues in the animals examined besides the small intestine and the omasum and rumen in sheep and dairy cows. Because the full-length cDNA probe may be more sensitive, distributions of the peptide transporter among other tissues such as liver, kidney, and skeletal muscles can be examined. This may provide a more accurate view of the tissue distribution of the peptide transporter in these animals.

In general, this research has demonstrated the wide existence of the mRNA for a peptide transporter in sheep, dairy cows, pigs, and chickens. The tissue distribution of this mRNA in these animals has also been demonstrated. This will facilitate the future cloning and further characterization of the peptide transporter in these farm animals. 


\section{Literature cited}

Amasheh, S., U. Wenzel, M. Boll, D. Dorn, W.-M. Weber, W. Clauss, and H. Daniel. 1997. Transport of charged dipeptides by the intestinal H+/peptide symporter PepT1 expressed in Xenopus laevis oocytes. J. Membrane Biol. 155:247-256.

Baker, R. D., and M. J. George. 1971. Pattern of neutral amino acid uptake along rat small intestine. Biochem. Biophys. Acta. 225:315-325.

Boll, M., D. Markovich, W.-M. Weber, H. Korte, H. Daniel, and H. Murer. 1994. Expression cloning of a cDNA from rabbit small intestine related to proton-coupled transport of peptides, $\beta$-lactam antibiotics and ACE-inhibitors. Eur. J. Physiol. 429:146-149.

Boll, M., M. Herget, M. Wagener, W.-M. Weber, D. Markovich, J. Biber, W. Clauss, H. Murer, and H. Daniel. 1996. Expression cloning and functional characterization of the kidney cortex high-affinity proton-coupled transporter. Proc. Natl. Acad. Sci. USA. 93:284-289.

Brandsch, M., C. Brandsch, P. D. Prasad, V. Ganapathy, U. Hopfer, and F. H. Leibach. 1995. Identification of a renal cell line that constitutively expresses the kidneyspecific high-affinity $\mathrm{H}^{+} /$peptide cotransporter. FASEB J. 9:1489-1496.

Brandsch, M. C. Brandsch, M. E. Ganapathy, C. S. Chew, V. Ganapathy, and F. H. Leibach. 1997. Influence of proton and essential histidyl residues on the transport kinetics of the $\mathrm{H}^{+}$/peptide cotransport systems in intestine (PEPT1) and kidney (PEPT2). Biochim. Biophys. Acta. 1324:251-262. 
Daniel, H. and S. A. Adibi. 1995. Selective effect of zinc on uphill transport of oligopeptides into kidney brush border membrane vesicles. FASEB J. 9:11121117.

Daniel, H. 1996. Function and molecular structure of brush border membrane peptide/ $\mathrm{H}^{+}$symporters. J. Membrane Biol. 154:197-203.

Daniel, H. and M. Herget. 1997. Cellular and molecular mechanisms of renal peptide transport. Am. J. Physiol. 273:F1-F8.

Dantzig, A. H., J. Hoskins, L. B. Tabas, S. Bright, R. L. Shepard, I. L. Jenkins, D. C. Duckworth, J. R. Sportsman, D. Mackensen, P. R. Rosteck, Jr., and P. L. Skatrud. 1994. Association of intestinal peptide transport with a protein related to the cadherin superfamily. Science. 264:430-433.

Doring, F., D. Dorn, U. Bachfischer, S. Amasheh, M. Herget, and H. Daniel. 1997. Functional analysis of a chimeric mammalian peptide transporter derived from the intestinal and renal isoforms. J. Physiol. 497:773-779.

Erickson, R. H., J. R. Gum, Jr., M. M. Lindstrom, D. McKean, and Y. S. Kim. 1995. Regional expression and dietary regulation of rat small intestinal peptide and amino acid transporter mRNAs. Biochem. Biophys. Res. Commun. 216:249-257.

Fei, Y.-J., Y. Kanal, S. Nussberger, V. Ganapathy, F. H. Leibach, M. F. Romero, S. K. Singh, W. F. Boron, and M. A. Hediger. 1994. Expression cloning of a mammalian proton-coupled oligopeptide transporter. Nature. 368:563-566.

Fei, Y.-J., W. Liu, P. D. Prasad, R. Kekuda, T. G. Oblak, V. Ganapathy, and F. H. Leibach. 1997. Identification of the histidyl residue obligatory for the catalytic 
activity of the human $\mathrm{H}+$ /peptide cotransporters PEPT1 and PEPT2. Biochemistry. $36: 452-460$.

Freeman, T. C., A. J. Collins, R. P. Heavens, and D. R. Tivey. 1993. Genetic regulation of enterocyte function: a quantitative in situ hybridization study of lactase-phlorizin hydrolase and $\mathrm{Na}^{+}$-glucose cotransporter mRNAs in rabbit small intestine. Pflugers Arch. 422:570-576.

Freeman, T. C. 1995. Parallel patterns of cell-specific gene expression during enterocyte differentiation and maturation in the small intestine of the rabbit. Differentiation. 59:179-192.

Freeman, T. C., B. S. Bentsen, D. T. Thwaites, and N. L. Simmons. 1995a. $\mathrm{H}^{+} / \mathrm{di}-$ tripeptide transporter (PepT1) expression in the rabbit intestine. Eur. J. Physiol. 430:394-400.

Freeman, T. C., A. Howard, B. S. Bentsen, S. Legon, and J. R. F. Walters. 1995b. Cellular and regional expression of transcripts of the plasma membrane calcium pump PMCA1 in rabbit intestine. Am. J. Physiol. 269:G126-G131.

Ganapathy, M. E., M. Grandsch, P. D. Prasad, V. Ganapathy, and F. H. Leibach. 1995. Differential recognition of beta-Lactam antibiotics by intestinal and renal peptide transporters, PEPT1 and PEPT2. J. Biol. Chem. 270:25672-25677.

Ganapathy, M. E., P. D. Prasad, B. Mackenzie, V. Ganapathy, and F. H. Leibach. 1997. Interaction of anionic cephalosporins with the intestinal and renal peptide transporters PEPT1 and PEPT2. Biochim. Biophys. Acta. 1324:296-308. 
Inui, K. I., Y. Tomita, T. Katsura, T. Okano, M. Takano, and R. Hori. 1992. $\mathrm{H}^{+}$-coupled active transport of bestatin via the dipeptide transport system in rabbit intestinal brush-border membranes. J. Pharmacol. Exp. Ther. 260:482-486.

Leibach, F. H. and V. Ganapathy. 1996. Peptide transporters in the intestine and the kidney. Annu. Rev. Nutr. 16:99-119.

Liang, R., Y.-J. Fei, P. D. Prasad, S. Ramamoorthy, H. Han, T. L. Yang-Feng, M. A. Hediger, V. Ganapathy, and F. H. Leibach. 1995. Human intestinal H+/peptide cotransporter cloning, functional expression, and chromosomal localization. J. Biol. Chem. 270:6456-6463.

Lister, N., P. D. Bailey, I. D. Collier, C. A. R. Boyd, and J. R. Bronk. 1997. The influence of luminal $\mathrm{pH}$ on transport of neutral and charged dipeptides by rat small intestine, in vitro. Biochim. Biophys. Acta. 1324:245-250.

Liu, W., R. Liang, S. Ramamoorthy, Y.-J. Fei, M. E. Ganapathy, M. A. Hediger, V. Ganapathy, and F. H. Leibach. 1995. Molecular cloning of PEPT 2, a new member of the $\mathrm{H}+$ / peptide cotransporter family, from human kidney. Biochim. Biophys. Acta. 1235:461-466.

Lochs, H., P. E. Williams, E. L. Morse, N. N. Abumrad, and S. A. Adibi. 1988. Metabolism of dipeptides and their constituent amino acids by liver, gut, kidney and muscle. Am. J. Physiol. 254:E588-E594.

Mackenzie, B., D. D. F. Loo, Y.-J. Fei, W. Liu, V. Ganapathy, F. H. Leibach, and E. M. Wright. 1996. Mechanisms of the human intestinal $\mathrm{H}^{+}$-coupled oligopeptide transporter hPEPT1. J. Biol. Chem. 271:5430-5437. 
Matthews, D. M. 1991. Protein Absorption: Development and Present State of the Subject. Wiley-liss, Inc. New York.

Matthews, J. C. and K. E. Webb, Jr. 1995. Absorption of L-Carnosine, L-Methionine, and L-methionylglycine by isolated sheep ruminal and omasal epithelial tissue. J. Anim. Sci. 1995. 73:3464-3475.

Matthews, J. C., E. A. Wong, P. K. Bender, J. R. Bloomquist, and K. E. Webb, Jr. 1996. Demonstration and characterization of dipeptide transport system activity in sheep omasal epithelium by expression of mRNA in Xenopus laevis oocytes. J. Anim. Sci. 74:1720-1727.

Meredith, D., and C. A. R. Boyd. 1995. Oligopeptide transport by epithelial cells. J. Membrane Biol. 145:1-12.

Miyamoto, K.-I., T. Shiraga, K. Morita, H. Yamamoto, H. Haga, Y. Taketani, I. Tamai, Y. Sai, A. Tsuji, and E. Takeda. 1996. Sequence, tissue distribution and developmental changes in rat intestinal oligopeptide transporter. Biochim. Biophys. Acta. 1305:34-38.

Muller, U., M. Brandsch, P. D. Prasad, Y.-J. Fei, V. Ganapathy, and F. H. Leibach. 1996. Inhibition of the $\mathrm{H}^{+}$/peptide cotransporter in the human intestinal cell line Caco-2 by cyclic AMP. Biochem. Biophys. Res. Commun. 218:461-465.

Nussberger, S. A. Steel, D. Trotti, M. F. Romero, W. F. Boron, and M. A. Hediger. 1997. Symmetry of H+ binding to the intra and extracellular side of the H+coupled oligopeptide cotransporter PepT1. J. Biol. Chem. 272:7777-7785. 
Ogihara, H., H. Saito, B.-C. Shin, T. Terada, S. Takenoshita, Y. Nagamachi, K.-I. Inui, and K. Takata. 1996. Immuno-localization of $\mathrm{H}+$ /peptide cotransporter in rat digestive tract. Biochem. Biophys. Res. Commun. 220:848-852.

Pan, Y., P. K. Bender, R. M. Akers, and K. E. Webb, Jr. 1996. Methionine-containing peptides can be used as methionine sources for protein accretion in cultured $\mathrm{C}_{2} \mathrm{C}_{12}$ and MAC-T cells. J. Nutr. 126:232-241.

Pan, Y.-X., E. A. Wong, J. R. Bloomquist, and K. E. Webb, Jr. 1997. Poly(A) ${ }^{+}$RNA from sheep omasal epithelium induces expression of a peptide transport protein(s) in Xenopus laevis oocytes. J. Anim. Sci. 75:3323-3330.

Pan, Y., and K. E. Webb, Jr. 1998. Peptide-bound methionine as methionine sources for protein accretion and cell proliferation in primary cultures of ovine skeletal muscle. J. Nutr. 128:251-256.

Phillips, W. A., K. E. Webb, Jr., and J. P. Fontenot. 1976. In vitro absorption of amino acid by the small intestine of sheep. J. Anim. Sci. 42:201-207.

Phillips, W. A., K. E. Webb, Jr., and J. P. Fontenot. 1979. Characteristics of threonine, valine, and methionine absorption in the jejunum and ileum of sheep. J. Anim. Sci. 48:926-933.

Puissant, C., and L.-M. Houdebine. 1990. An improvement of the single-step method of RNA isolation by acid guanidinium thiocyanate-phenol-chloroform extraction. BioTechniques 8:148-149.

Saito, H., M. Okuda, T. Terada, S. Sasaki, and K.-I. Inui. 1995. Cloning and characterization of a rat $\mathrm{H}^{+} /$peptide cotransporter mediating absorption of beta- 
lactam antibiotics in the intestine and kidney. J. Pharmacol. Exp. Therap. 275:1631-1637.

Saito, H., T. Terada, M. Okuda, S. Sasaki, and K.-I. Inui. 1996. Molecular cloning and tissue distribution of rat peptide transporter PEPT2. Biochim. Biophys. Acta. 1280:173-177.

Sambrook, J., E. F. Fritsch, and T. Maniatis. 1989. Molecular cloning: a laboratory manual (2nd Ed.). Cold Spring Harbor, NY.

Steel, A., S. Nussberger, M. F. Romero, W. F. Boron, C. A. R. Boyd, and M. A. Hediger. 1997. Stoichiometry and $\mathrm{pH}$ dependence of the rabbit proton-dependent oligopeptide transporter PepT1. J. Physiol. 498:563-569.

Swaan, P. W., M. F. C. Stehouwer, and J. J. Tukker. 1995. Molecular mechanisms for the relative binding affinity to the intestinal peptide carrier. Comparison of three ACE inhibitors: enalapril, enalaprilat, and lisinopril. Biochim. Biophys. Acta. 1236:31-38.

Tacnet, F., F. Lauthier, and P. Ripoche. 1993. Mechanisms of zinc transport into pig small intestine brush-border membrane vesicles. J. Physiol. 465:57-72.

Wang, S., K. E. Webb, Jr., and M. R. Akers. 1996. Peptide-bound methionine can be a source of methionine for the synthesis of secreted proteins by mammary tissue explants from lactating mice. J. Nutr. 126:1662-1672.

Wenzel, U., I. Gebert, H. Weintraut, W.-M. Weber, W. Claub, and H. Daniel. 1996. Transport characteristics of differently charged cephalosporin antibiotics in oocytes expressing the cloned intestinal peptide transporter PepT1 and in human intestinal Caco-2 cells. J. Pharmacol. Exp. Therap. 277:831-839. 
Wilson, J. W., and K. E. Webb, Jr. 1990. Lysine and methionine transport by bovine jejunal and ileal brush border membrane vesicles. J. Anim. Sci. 68:504-514.

Yamashita, T., S. Shimada, W. Guo, K. Sato, E. Kohmura, T. Hayakawa, T. Takagi, and M. Tohyama. 1997. Cloning and functional expression of a brain peptide/histidine transporter. J. Biol. Chem. 272:10205-10211. 


\section{VITA}

Hong Chen, daughter of Qiming Chen and Yuwen Liu, was born in March, 1968

in Lanzhou, Gansu, P. R. China. She was graduated from Lanzhou University with a Bachelor of Science degree in cell biology in July, 1990. She married YuanXiang Pan in August, 1992. She came to Virginia Tech in August, 1996 and initiated her program of master's study in animal nutrition.

She is a member of The American Society of Animal Science.

Hong Chen 